\title{
THE USE OF GOVERNMENT-INITIATED REFERENDUMS IN LATIN AMERICA. TOWARDS A THEORY OF REFERENDUM CAUSES
}

El uso de los referendos de iniciativa gubernamental en América Latina. Hacia una teoría sobre las causas del uso de votaciones populares iniciadas por el gobierno

\author{
ANITA BREUER \\ Department of Comparative Politics, University of Cologne
}

\begin{abstract}
Over the past two decades there has been a considerable increase in the number of referendums worldwide. The existing literature on direct democracy has so far failed to explain this phenomenon by delivering a consistent theory on the causes of referendums. This explorative study aims at undertaking steps toward closing this gap by focusing on the specific type of facultative government-initiated referendums (FGIR) and their use in presidential systems. Using QCA (a case-sensitive technique based on the formal logic of Boolean algebra), this study systematically compares the political opportunity structures of 49 presidential systems from 12 Latin American countries to detect the factors that spurred or obstructed the occurrence of FGIR. It concludes that FGIR are closely linked to high levels of party system fragmentation and divided government, i.e. two factors which have long been deemed problematic in the context of presidential systems, while their obstruction is mainly owed to the specific constitutional provisions regulating the referendum device.
\end{abstract}

Keywords: Referéndums, Latin America, Fragmentation, Direct Democracy.

\section{RESUMEN}

En las últimas dos décadas ha existido alrededor del mundo un considerable aumento en el número de votaciones populares. Sin embargo, la literatura existente sobre democracia directa no ha sabido explicar el fenómeno mediante una teoría consistente de las causas de los referéndums. Este estudio exploratorio busca dar un paso adelante para cerrar esta brecha, enfocándose en los referendum facultativos iniciados por poderes politicos formales (facultative government-initiated referendums - FGIR) y su uso en los sistemas presidenciales. Utilizando QCA (técnica basada en lógica formal de álgebra booleanas), este estudio hace una comparación sistemática de la estructura de oportunidades políticas de 49 sistemas presidenciales de 12 países de América Latina, para detectar los factores que estimulan u obstruyen la ocurrencia de FGIR. Se concluye que los FGIR están fuertemente ligados a altos niveles de fragmentación partidaria y gobiernos divididos, dos factores que han sido problemáticos en los contextos de sistemas presidenciales. Por su parte, la obstrucción se debe principalmente a provisiones constitucionales específicas que regulan los dispositivos de las votaciones populares iniciadas por el gobierno.

Palabras Clave: Plebiscito, América Latina, fragmentación, democracia directa. 


\section{INTRODUCTION ${ }^{1}$}

From the 1960s onwards, various nations of the world embraced the idea of direct democracy and over the past two decades, the practical application of direct democratic instruments has increased considerably (LeDuc, 2003). ${ }^{2}$ This trend has attracted scholarly attention and over recent years, considerable research investigating direct democracy has been published in renowned journals in the field of political science. So far this literature has mainly focused on the two countries that most frequently use referendums, Switzerland and the United States on the state level (Ladner and Brändle, 1999; Gerber, 1996; Papadopulos, 2001; Tolbert and Hero, 1996; Vatter and Freitag, 2006), while a smaller number of publications have focused on the wave of referendums entailed in the process of European integration (Hug and Sciarini, 2000; Franklin et al., 1995). These publications have greatly contributed to our knowledge regarding the impact of referendums on politics and on diverse societal aspects. However, they have not yet produced a consistent theory on the causes of referendums. The objective of this paper is to undertake initial steps towards bridging this gap.

To a large extent, the 'boom' in direct democracy can be credited toward the increased number of citizen-initiated referendums and, to a lesser extent, mandatory referendums (Morel, 2001) This development has been welcomed by advocates of direct democracy who emphasize the potential of these tools to foster bottom-up participation and vertical accountability (Barber, 1984; Schmitter, 2000). Nevertheless, on several occasions, nonmandatory referendums on important political questions have been initiated by governing bodies i.e. legislatures or executives. Such government-initiated referendums, which are often referred to as plebiscites, ${ }^{3}$ a term that carries a slight negative connotation, largely retain control over political decision-making in the hands of elected officials.

Despite contributing little to the overall increase in direct democracy, the occurrence of facultative government-initiated referendums (FGIR) ${ }^{4}$ poses a theoretical puzzle (Rahat, 2007).

1 I would like to thank Kathryn Hochstetler and Aníbal Pérez Liñán for generously sharing their data. Research for this article was begun at the 2006 Summer School in Methods and Techniques of the European Consortium for Political Research under the guidance of Prof. Benoit Rihoux, who patiently continued to advise me on the manuscript at its several stages of development. The manuscript has also profited greatly from the constructive critiques of two anonymous reviewers. All remaining mistakes and deficits are, of course, my sole responsibility.

2 It is important to note though, that the observed increase refers to the average number of direct democratic events at the national level per annum. However, if put in relation to the increase in number of independent nations that have credible claims to be democracies it seems that the practical use of direct democracy has maintained constant over the past twenty years (Altman, 2007; Butler \& Ranney, 1994).

3 As Suksi (1993) has pointed out, this negative connotation goes back to the abuse of the so-called Napoleonic referendums during the nineteenth century. He therefore argues that a term with 'a meaning as distorted as that of 'plebiscite' is not very useful to denote referendums within the framework of modern national decision-making (Suksi, 1993, p. 11). Following this argument, in this study the term plebiscite is reserved for the designation of ad hoc consultations that are held without a pre-existing legal basis at the discretion of a particular political agent. Whereby the term 'referendum' is used to denominate constitutionally regulated popular consultations, which are triggered by governing authorities.

4 The word 'government' is used in a generic fashion here, designating governing authorities in general, i.e. members of both executive and legislative branch of government. 
While it is understandable that citizens will participate in processes of decision-making when given the right to do so, political elites' use of direct democratic instruments is harder to comprehend. What motivates governing authorities to initiate referendums? Why should democratically legitimised representatives voluntarily give up their monopoly to legislate, redistribute power downwards, equal themselves with ordinary citizens in political decision-making, and ultimately expose themselves to the risk of losing at the ballot box? The central aim of this explorative study is to provide potential answers to these questions.

\section{CASE SELECTION, HYPOTHESES AND METHODOLOGY}

Despite warnings against small-n studies and the related pitfall of selection biases, which have been raised in methodological writings on comparative politics (Geddes, 2003; King et al., 1994), scholars whishing to conduct explorative studies outside overarching theoretical programs are well advised to restrict their analysis to small homogeneous groups of relevant cases (Brady et al., 2004; Mahoney, 2007). Therefore, this study focuses on Latin America as a region where direct democratic practice has been dominated by FGIR. From the 1980s onwards, most Latin American countries adopted institutions of direct democracy and today the region's constitutions provide for a wide variety of direct democratic instruments. Despite this variety, we find ourselves confronted with the apparent paradox that direct democracy in Latin America has mainly remained a top-down affair. Practical applications of bottom-up instruments have been scarce and exceptional with 87 percent of all national level direct democratic events occurring in Latin America during the twentieth and early twenty-first century, being initiated by governing authorities (Altman, 2005). Against this background, the region provides an interesting laboratory for the formulation and testing of hypotheses on the causes of the occurrence of FGIR. In political science literature on Latin America, the issue has almost exclusively been dealt with in analyses on the rise to power and government style of political outsiders (Barr, 2003; Ellner, 2003; Leaman, 1995; Mayorga, 2002; Philip, 1998). Following Weyland's definition of neo-populism as 'a political strategy through which a personalistic leader seeks or exercises government power based on direct, unmediated, uninstitutionalized support from large numbers of mostly unorganized followers' (Weyland, 2003, 1067), the use of FGIR has been interpreted as part of the strategic tool box of neo-populist leadership. However, neopopulism and referendum occurrence are not inextricably linked. While it is true that some Latin American neo-populist leaders like Peru's Fujimori and Venezuela's Chávez employed FGIR, others like Argentina's Menem and Brazil's Collor de Mello did not. This demonstrates that although leadership style as an independent variable may be decisive in explaining political phenomena, it cannot be predicted by any model (Linz and Stepan, 1978, 4-5). Hence, if we wish to analyze the factors that cause FGIR, we will have to go beyond the conventional actor-centered approach and direct our attention toward the opportunity structures within which political actors operate.

Observing the direct democratic practice in post-transitional Latin America, we find that in those countries where the constitutions uphold the use of FGIR, there has been a great 
variance in the frequency of FGIR. In Ecuador, for example, four events occurred between 1980 and 2005, whereas in Guatemala, where referendums were constitutionalized in 1985, no single FGIR has been held to date. ${ }^{5}$ This variance indicates that certain political opportunity structures are conducive to FGIR, while others work to their obstruction. The literature on direct democracy has so far concentrated on a few selected cases with practical experience in the use of direct democratic instruments. However, if we wish to understand the opportunity structures that are conducive to the use of FGIR, we have to avoid the methodological error of selecting on the value of the outcome variable. Causality cannot be inferred by an analysis that is limited to positive cases where referendums were held, instead these positive cases have to be compared against a control group of comparable negative cases (Geddes, 1990; Lijphart, 1971).

\section{Defining the Universe of Analysis}

In this study, the outcome of interest, i.e. the occurrence of Facultative Government Initiated Referendums (FGIR) defined as facultative referendums which may be triggered either by the executive, and/or a given number or percentage of members of the legislature, or the executive and legislative branch of government in co-operation, is analyzed at the macro-level of political systems. However, considering the event character of our outcome variable and that opportunity structures which shape the decisions of political actors are prone to change over time, it is not sensible to choose nation-states as analytical units. Instead this study disaggregates nation-states into country-administrations and treats each administration as one observational unit.

In order to ensure the minimum unit-homogeneity, which is necessary for a meaningful comparison in qualitative research (Munck, 2004; Ragin, 1992), the analysis is restricted to: firstly, the political systems of Latin America without the Caribbean, secondly, those which belong to purely presidential regimes, thirdly, within the period of 1980-2005, and lastly, where a FGIR could have likely occurred. ${ }^{6}$ The latter criterion requires further explanation. Qualitative research often aims at the explanation of rare phenomena, e.g. wars. Hence, while the number of observational units bearing a positive outcome is necessarily small, the number of corresponding units with a negative outcome, e.g. nonwars, is potentially infinite, and including too many of them involves the risk of biased results. In order to reduce the number of negative units, this study adopts the 'possibility principle' presented by Mahoney and Goertz (2004). This principle postulates that only

\footnotetext{
The country, though, saw two events of mandatory referendums on constitutional reform in 1994 and 1999. Outside Latin America, during the period of observation full fledged presidential systems existed in the United States, Ghana, Nigeria, Uganda, South Korea, and the Philippines. Out of these countries only the Philippines know facultative government initiated referendums on the national level. Like Latin America, the Philippines were originally colonized by Spain. Different from the Latin American countries however, following the end of Spanish colonial rule in 1898, the Philippines experienced almost half a century of US-American tutelary rule, which left a deep impact on its political culture (Go 1999 and 2008). Colonial heritage and political culture are rightly considered an important differentiating variable in empirical political analysis (Lijphart, 1984; Lane, 1992). The Philippines were therefore excluded from this analysis in order to ensure the homogeneity of our population of relevant cases.
} 
those units where the outcome of interest has a real possibility of occurrence should be included, while units where the outcome merely has a non-zero probability should be relegated to the set of uninformative and hence irrelevant observations. In this study, the criterion chosen to distinguish between negative and irrelevant observations is the existence of legal provisions for FGIR on the national level during the observational period. Invoking Suksi's (1993) terminology, the analysis will be restricted to units in which a 'pre-regulated referendum' held according to constitutionally or other legal norms was possible, while it will not contemplate the possibility of 'ad hoc plebiscites' held at the discretion of a particular political agent.

While the possibility principle actually filters out a number of positive cases, a closer look at the nature of the excluded referendum events reveals that it is a sensible criterion with regard to case homogeneity.

The Chilean plebiscites of 1980, 1988, and 1989 were convoked by the Pinochet military government and paved the way to the country's democratic restoration. The Venezuelan plebiscites of April and December 1999 on the convocation of a constituent assembly, the electoral law for the election of constituent assembly delegates and the ratification of the constitution drafted by the assembly were convoked by decrees of president Chávez. They followed the complete collapse of Venezuela's traditional party system in 1998 (McCoy, 199; Morgan, 2007) and marked the starting point to the process of uprooting the country's established political institutions. The Colombian plebiscite on constitutional reform of 1990 was convoked by a decree of president Gaviria and subsequently declared binding by the Supreme Court. It took place amid a wave of extreme violent intimidation against the public launched by the Colombian drug cartels. The agenda of the plebiscite had been framed by the student movement La Septima Papeleta (the seventh ballot) which regarded it as the only possible solution to address the rampant political crisis that had resulted from the failure of the traditional political class to address the inadequacy and corruptness of the country's political institutions (Van Cott, 2000).

It appears, then, that while such ad-hoc plebiscites obviously play an important role when analyzing different processes of regime transformation, they are not well placed in a study that seeks to investigate the strategic choices of political actors in routinely democratic decision making processes.

Altogether, these criteria constitute a set of 49 administrations from twelve Latin American countries, ${ }^{7}$ which are displayed in Table 1.

7 Our selection criteria exclude the case of Uruguay. Although the country is the region's most frequent user of direct democracy, it does not belong to our universe of analysis since its constitution does not provide for facultative government initiated referendums. In Uruguay, any decision to alter the constitution necessarily requires ratification by popular vote in a mandatory referendum, whilst the right to trigger referendums on ordinary legislation is reserved to citizens. Another referendum event excluded by the restriction to legally pre-regulated referendums is the Argentinean plebiscite of 1994 on the border dispute with Chile over the Beagle Channel zone, which was convoked following an accord between President Alfonsín and the Supreme Court. 
Table 1: Latin American Administrations Constituting the Universe of Analysis

\begin{tabular}{|c|c|c|}
\hline Country & Administration & Case Id \\
\hline Argentina & $\begin{array}{l}\text { Carlos Menem, 1989-1995 } \\
\text { Carlos Menem, 1995-1999 } \\
\text { Fernando de la Rúa, 1999-2001 } \\
\text { Eduardo Duhalde, 2002-2003 } \\
\text { Néstor Kirchner, } 2003 \text { to date }\end{array}$ & $\begin{array}{l}\text { ARGMen1 } \\
\text { ARGMen2 } \\
\text { ARGRua } \\
\text { ARGDuh } \\
\text { ARGKir }\end{array}$ \\
\hline Bolivia & $\begin{array}{l}\text { Carlos Mesa, 2003-2005 } \\
\text { Eduardo Rodríguez, 2005-2006 }\end{array}$ & $\begin{array}{l}\text { BOLMes } \\
\text { BOLRod }\end{array}$ \\
\hline Brazil & $\begin{array}{l}\text { José Sarney, 1985-1990 } \\
\text { Fernando Collor de Mello, 1990-1992 } \\
\text { Itamar Franco, 1992-1995 } \\
\text { Fernando Cardoso, 1995-1999 } \\
\text { Fernando Cardoso, 1999-2003 } \\
\text { Luiz Ignácio Lula da Silva, 2003-2006 }\end{array}$ & $\begin{array}{l}\text { BRASar } \\
\text { BRACol } \\
\text { BRAFra } \\
\text { BRACar1 } \\
\text { BRACar2 } \\
\text { BRALul }\end{array}$ \\
\hline Chile & $\begin{array}{l}\text { Patricio Aylwin, 1990-1994 } \\
\text { Eduardo Frei Ruiz, 1994-2000 } \\
\text { Ricardo Lagos, 2000-2006 }\end{array}$ & $\begin{array}{l}\text { CHIAyl } \\
\text { CHIFre } \\
\text { CHILag }\end{array}$ \\
\hline Colombia & $\begin{array}{l}\text { César Gaviria, 1990-1994 } \\
\text { Ernesto Samper, 1994-1998 } \\
\text { Andrés Pastrana, 1998-2002 } \\
\text { Álvaro Uribe, 2002-2006 }\end{array}$ & $\begin{array}{l}\text { COLGav } \\
\text { COLSam } \\
\text { COLPas } \\
\text { COLUri }\end{array}$ \\
\hline Costa Rica & Abel Pacheco, 2002-2006 & COSPac \\
\hline Ecuador & $\begin{array}{l}\text { Jaime Roldós, 1979-1981 } \\
\text { Osvaldo Hurtado, 1981-1984 } \\
\text { León Febres Cordero, 1984-1988 } \\
\text { Rodrigo Borja, 1988-1992 } \\
\text { Sixto Durán Ballén, 1992-1996 } \\
\text { Abdalá Bucaram, 1996-1997 } \\
\text { Fabián Alarcón, 1997-1998 } \\
\text { Jamil Mahuad, 1998-2000 } \\
\text { Gustavo Noboa, 2000-2003 } \\
\text { Lucio Gutierrez, 2003-2005 }\end{array}$ & $\begin{array}{l}\text { ECURol } \\
\text { ECUHur } \\
\text { ECUFeb } \\
\text { ECUBor } \\
\text { ECUDur } \\
\text { ECUBuc } \\
\text { ECUAla } \\
\text { ECUMah } \\
\text { ECUNob } \\
\text { ECUGut }\end{array}$ \\
\hline Guatemala & $\begin{array}{l}\text { Marco Cerezo, 1986-1991 } \\
\text { Jorge Serrano, 1991-1993 } \\
\text { Ramiro de León Carpio, 1993-1996 } \\
\text { Alvaro Arzú, 1996-2000 } \\
\text { Alfonso Portillo, 2000-2004 } \\
\text { Óscar Berger, 2004 to date }\end{array}$ & $\begin{array}{l}\text { GUACer } \\
\text { GUASer } \\
\text { GUALeo } \\
\text { GUAArz } \\
\text { GUAPor } \\
\text { GUABer }\end{array}$ \\
\hline Nicaragua & $\begin{array}{l}\text { Violeta Barrios de Chamorro, 1990-1997 } \\
\text { Arnoldo Alemán, 1997-2002 } \\
\text { Enrique Bolaños, 2002-2007 }\end{array}$ & $\begin{array}{l}\text { NICBar } \\
\text { NICAle } \\
\text { NICBol }\end{array}$ \\
\hline Paraguay & $\begin{array}{l}\text { Andrés Rodríguez, 1989-1993 } \\
\text { Juan Carlos Wasmosy, 1993-1998 } \\
\text { Raúl Cubas Grau, 1998-1999 } \\
\text { Luis González Macchi, 1999-2003 } \\
\text { Nicanor Duarte, } 2003 \text { to date }\end{array}$ & $\begin{array}{l}\text { PARRod } \\
\text { PARWas } \\
\text { PARCub } \\
\text { PARGon } \\
\text { PARDua }\end{array}$ \\
\hline Peru & $\begin{array}{l}\text { Alberto Fujimori 1995-2000 } \\
\text { Alberto Fujimori, May 2000-Nov } 2000 \\
\text { Alejandro Toledo, 2001-2006 }\end{array}$ & $\begin{array}{l}\text { PERFuj2 } \\
\text { PERFuj3 } \\
\text { PERTol }\end{array}$ \\
\hline Venezuela & Hugo Chávez, 2000-2007 & VENCha2 \\
\hline
\end{tabular}




\section{Selection of Causal Conditions and Working Hypotheses}

Having defined our universe of cases, we can now address the central question of this study: why did FGIR occur during some of these administrations and why did they not occur during others although the constitution facilitated their usage? Since scholarly literature has not yet produced readily testable hypotheses on the causes of referendums in presidential systems, this study offers the tentative interpretation of FGIR being a strategy destined to overcome critical situations, which may typically arise in presidential systems. Such critical situations can be regarded as opportunity structures in which different factors combine to produce a configurational condition that renders the holding of a referendum a particularly attractive strategic option for political actors.

The assumption is that such opportunity structures will be specific configurations of short-term contextual factors that acutely threaten the survival of the administration in turn, medium-term factors that tend to be stable throughout administrations affecting the political power balance and, long-term institutional factors whose structuring effects on political decision-making are stable over several administrations. The hypotheses and pertaining causal conditions presented below, were elaborated following a strategy of going back and forth between theory and evidence (Ragin, 1987; Rihoux and Ragin, 2009). I.e. in a first step, hypotheses were derived deductively based on the main theoretical perspectives in the literature on presidentialism and direct democracy. In a second step, the author referred back to the empirical cases in order to detect additional causal conditions, verify the correct operationalization of conditions and re-specify the analytical model.

\section{a) Short-Term Factors}

According to Linz (1990), presidential systems are prone to inter-branch conflict due to the independent origin and survival of the executive and legislative branches of government. However, there are no institutional mechanisms to resolve such conflicts since legislatures do not dispose of a vote of non-confidence to remove a president, nor are presidents entitled to dissolve congress and call for pre-term elections. This can lead to acute crises whereby the president negates the legitimacy of congress, congress requests the destitution of the president, or one of the elective powers supports a military intervention to close down the other (Pérez-Liñán, 2003). In such a situation, political actors from either branch may resort to a referendum in order to bolster their legitimacy against their rivals and avert their overthrow.

\section{H1: Acute presidential crises are conducive to FGIR}

Another distinctive feature of presidentialism is the high visibility of the office of the president who 'is taken to be the embodiment of the nation and the main custodian and definer of its interest' (O'Donnell, 1996). The high public expectations entailed herewith may have devastating consequences for presidents who fail to fulfill them. As Hochstetler (2006) has shown, over the past years, street protests by mass publics frustrated with presidential performance have played an increasingly important role in presidential falls. Presidents 
facing situations of civil unrest may attempt to use referendums to several strategic ends: a) as a means to divert public attention from unpopular policies or personal misdemeanor, b) as a political offering to mobilized groups of citizens (Barczak, 2001a), c) as a way to delegate responsibility for unpopular decisions by 'passing the buck to the voter' (Butler and Ranney, 1994, 20; Setälä, 2006).

H2: High levels of civil unrest are conducive to FGIR

\section{b) Medium-term Factors}

Multiparty systems constitute a sizeable subset of Latin America's presidential democracies and some scholars have argued that conflict and its persistence are even more likely under multiparty situations, which make inter-branch negotiation more difficult and exacerbate existing problems of presidentialism (Mainwaring, 1993; Jones, 1995). In such a situation, the executive or oppositional legislators could use a referendum in order to outplay their political rivals in the opposite branch of government.

\section{H3: High levels of party system fragmentation are conducive to FGIR}

As the number of parties increases, so does the likelihood of divided government defined as a situation in which the president's party does not control a majority of legislative seats, or in bicameral systems, a majority of seats in at least one of the chambers. ${ }^{8}$ One possible implication of divided government is a stalemate between congress and the president. In such a situation, political actors may either opt to bargain out of a deadlock or to pursue their policy goals with the resources available to whatever branch of government they control (Cox and Kernell, 1991). The referendum is one such resource which, depending on the specific constitutional regulations, may be an exclusive resource of the legislature, or the executive, or available to both branches.

\section{H4: Divided government is conducive to FGIR}

Under normal circumstances, the head of executive in a presidential system is selected via direct elections. However, fixed mandates, as a distinctive feature of presidential regimes, may lead to a situation in which the effective head of executive lacks such direct democratic legitimation. Depending on the constitutional provisions which apply in case of an early termination of a president's term, the automatic successor may have occupied a non-elective post prior to the assumption of office, or may have been appointed by the president as his running mate without consideration of his ability to maintain popular support (Linz, 1990). Such an automatic successor may be tempted to compensate for his lack of direct legitimation by using a referendum as a popular vote of confidence rather than a vote on a specific policy issue.

H5: Missing direct democratic legitimation of the effective executive is conducive to FGIR 


\section{c) Long-Term Factors}

While the literature on presidentialism and direct democracy does not reveal much regarding possible long-term factors conducive to FGIR in presidential systems, some hints to that respect can be drawn from a comparison between Europe's and Latin America's practical record of direct democracy. Comparing these two regions, we find that they differ significantly with respect to the nature of issues put to popular consultation. FGIR in Europe tend to be single-issue votes. When European citizens are called to the polls by their governments, they normally have to decide on a specific piece of policy. Analyses of direct democratic events in Europe's mostly parliamentary systems have revealed that on several occasions such referendums were organized to remove a contested issue from the agenda in order to avoid negative repercussions in upcoming elections or to prevent a split in the governmental coalition (Morel, 2001; Setälä, 2006). Meanwhile, FGIR in Latin America's presidential systems appear to follow a different logic. ${ }^{9}$ Here, the implementation is generally related to constitutional reforms (Altman, 2005) and citizens often have to vote on entire catalogues of reform proposals. This suggests that FGIR in Latin America might be related to a high degree of constitutional rigidity, i.e. an amendment of the constitution requires a supra-majority whose fulfillment involves high transaction costs thus making a referendum an attractive alternative.

H6: Constitutional rigidity is conducive to FGIR

Mandatory referendums are rightly considered an important institutional barrier to constitutional reform and are therefore endogenous to several indices measuring constitutional rigidity (Lijphart, 1999; Anckar and Karvonen, 2002). However, this approach is not useful for the particular purpose of this study: the existence of a mandatory referendum on constitutional reforms renders facultative referendums on constitutional law impossible. Consequently, the absence of a mandatory referendum constitutes a necessary condition for the holding of a facultative referendum on constitutional reform, which is treated as a separate variable for the purpose of this study.

H7: The absence of provisions for mandatory referendums is a necessary but insufficient condition for the occurrence of any FGIR that involves constitutional reform

\section{Qualitative Comparative Analysis (QCA) as a Methodological Approach}

Quantitative, variable-orientated research operates on a probabilistic understanding of causality. It aims at isolating net effects of independent variables on a dependent variable in a randomly drawn sample. The standard regression techniques normally employed to this purpose rest on the assumption that the effect of independent variables on the dependent variable is linear and additive.

9 Possible reasons why these motifs carry less weight here could be that most Latin American presidents are banned from immediate reelection, as well as the substantial differences between presidential and parliamentary systems with regard to coalition formation and survival (Altman, 2000). 
This study, by contrast, aims at exploring the conditions that led to the outcome in a previously defined population of relevant cases and therefore requires a different research design. When it comes to analyzing the opportunity structures within which political decisions are made, operative variables may not be independent of each other at all. Effectively, in the real world of political decision-making, causally important variables are often bundled together and there may be alternative causal models producing the same outcomes (Ragin, 1987; Pierson and Skocpol, 2002).

QCA therefore offers a number of advantages for the purpose of this study. It is a case-sensitive technique based on the formal logic of Boolean algebra. While QCA is sometimes referred to as an advancement of Mill's methods of agreement and difference (Mill, 1865), it differs from them in an important aspect. The Millean methods operate on a deterministic understanding of causality. They focus on individual factors which are interpreted in terms of necessity and/ or sufficiency: A condition is interpreted as sufficient, if always when the condition is present, the outcome is also present, whereas a condition is necessary, if always when the outcome is present, the condition is also present. According to Mill's approach, causal conditions are independent of each other and there is only one causal path to the outcome.

QCA, by contrast, operates on the concept of multiple conjunctural causation that resembles the INUS approach to causation described by Mackie (1965). As Mackie stresses outcomes have, typically, a plurality of causes. That is, a certain outcome can be brought about by a number of distinct clusters of factors. Each cluster is sufficient to bring about the effect, but none of them is necessary. This means that individual factors are insufficient but nonredundant parts of an unnecessary but sufficient condition. This concept of multiple conjunctural causation enables the researcher to establish the number and character of the diverse configurational paths that lead to the outcome in need of explanation (Ragin, 1987; Mahoney, 2007).

The hypotheses formulated above should be interpreted in this vein. That is, while none of the causal conditions presented in section II. 2 is expected to be individually necessary or sufficient to bring about a referendum, it is assumed that an opportunity structure that renders a referendum an attractive strategy, will consist of different combinations of short term, medium term and long term factors.

\section{QCA PROCEDURES AND CASE STUDIES}

The first step of a Boolean consists of coding causal conditions and the outcome dichotomously as either "present" or "absent". Subsequently these binary data are collected in a truth table displaying all combinations of causal conditions and outcomes.

Concerning the outcome-"occurrence" or "non-occurrence" of a facultative referendumdichotomization is a straightforward task since this variable is binary in nature. The same holds true for the conditions of divided government $(D)$, missing direct democratic legitimation of the executive (M), and absence of provisions for mandatory referendums (A). For the interpretation of the qualitative evidence of the contextual factors presidential crises $(C)$ and civil unrest $(U)$, this study draws on the expertise of area scholars. Coding 
decisions regarding presence or absence of $C$ were taken on the basis of a qualitative dataset provided by Perez Liñan. ${ }^{10}$ Coding for $U$ in South America follows Hochstetler (2006), while coding decisions for the Central American countries are based on an unpublished dataset on protest events in presidential systems elaborated by the same scholar. ${ }^{11}$ Finally, levels of party system fragmentation $(P)$ and constitutional rigidity $(R)$ are continuous numerical and ordinal variables respectively, which makes it necessary to set dichotomization thresholds. For the coding of $P$, the effective number of parties (ENP) in lower chambers was calculated according to Laakso and Taagepeera (1979) and the threshold set at an ENP of 4.0, i.e. the break-off point between multi-party systems with a dominant party (3.5) and multi-party systems without a dominant party (4.5) (Blondel, 1968). The underlying assumption is that multi-party systems without a dominant party are more likely to produce divided government. For the dichotomization of $R$, I adapted Lijphart's (1999) index, which measures constitutional rigidity on an ordinal four-point scale with 1 indicating complete flexibility and 4 indicating maximum rigidity. For the reasons exposed in section II, the criterion of mandatory referendums was extricated from Lijphart's index and the threshold set at ordinal value $2 .{ }^{12}$

\section{Truth Table Construction}

Each of these binary conditions divides the universe of cases into two parts, i.e. our set of seven conditions divides the universe into $2^{7}=128$ possible combinations of conditions. Given the limited diversity of empirical phenomena, there are combinations which are logically possible but for which no empirical evidence was observed in the population under investigation. In our analysis, the number of unobserved combinations, referred to as 'logical remainders' in QCA-terminology, amounts to 93. As this paper aims at developing and testing theoretical hypotheses by an analysis of strictly observed cases these logical remainders were set to cero-a conservative approach adopted in other work using QCA (Hicks et al., 1995; Redding and Viterna, 1999; Yamasaki, 2003). ${ }^{13}$

10 Aníbal Perez Liñán, Associate Professor of Political Science, Department of Political Science, University of Pittsburgh.

11 Kathryn Hochstetler, Professor of Political Science, Department of Political Science, University of New Mexico.

12 The database on Political Opportunity Structures in Latin American Administrations (POSLAA) that constitutes the basis for this truth table was constructed in MS-Access. It consists of six inter-linked tables containing detailed qualitative and quantitative data as well as notes on coding decisions for the outcome and causal conditions. The author will supply the database upon request.

13 The treatment of logical remainders is a much debate dissue in the literature on configurational methodology. The attractiveness of their use lies in the fact that including logical remainders as simplifying assumptions into the Boolean minimization process will lead to more parsimonious solution terms. However, this practice has also attracted critique, e.g. by Markoff (1990) in whose opinion researchers who speculate what would happen under configurations of variables that do not actually exist are engaged in an imaginative act that will produce neat looking solutions that are essentially unverifiable. To reduce this risk, authors who advocate the inclusion of logical remainders have emphasized the importance of making theoretically informed choices. That is, the researcher should differentiate between logical remainders for which it is relatively easy to assign a given outcome value (because of clear theoretical expectations) and logical remainders for which it is difficult to assign a given outcome value, and exclude the latter (Ragin and Sonnett, 2004; Ragin and Rihoux, 2004). Given that political science literature has not yet produced a consolidated theory on referendum occurrence 
Of the 35 observed combinations, one happened to be a contradictory configuration. Such contradictory configurations occur when cases with identical values on relevant conditions display different values on the outcome variable. Several strategies on how to address contradictory configurations have been proposed. One strategy is to recode all contradictory configurations as [0] on the outcome value. This solution, suggested by Ragin (1987), treats contradictory configurations as 'unclear' and thus decides to accept fewer minimizable configurations in exchange for more consistency in the cases-outcome relationship (Rihoux and Ragin, 2009, p. 49). A more case informed strategy, is to re-examine the historical context of the cases involved in the specific contradictory configuration in order to detect conditions that have been previously missed out and differentiate the affected cases (Rihoux and Ragin, 2009).

A close re-examination of the contradictory case pair, the administrations of Fébres Cordero and Gutiérrez in Ecuador, revealed that these cases differed in the role adopted by the army vis a vis an acute executive legislative crisis. In 1986, when Congress initiated moves to impeach Febres Cordero, the military warned congressional leaders that it would shut down the legislature if a formal impeachment action were brought against the president thus enabling Febres to face down the removal effort and go ahead with a referendum to boost his tattered legitimacy (the case of Febres Cordero will be discussed in more detail in section III.3). Meanwhile, in the case of Gutiérrez the army denied its support to the president in a critical moment. In December 2004 Gutiérrez` decision to remove almost the entire Supreme Court, which he claimed to be biased against him, and replace it with loyal nominees sparked an executive legislative crisis. Amid growing street protests against his government, Gutiérrez declared a state of emergency and announced to hold a referendum in order to secure public approval for the new court (BBC 2005). In this situation, the army did not act to restore order and refused to enforce the state of emergency, leaving the president with no other option than to flee the presidential palace in a helicopter.

Notwithstanding the result of this contextual re-examination, the option of integrating the identified differentiating factor as an additional condition into the model to solve the contradiction was discarded. The sustained and particularly strong role of the Ecuadorian army as a moderating power in political matters is unparalleled in the contemporary Latin American context (Perez and Whitney, 2004), ${ }_{14}^{14}$ thus making it unlikely that active army involvement played a decisive role in referendum processes beyond Ecuador. Hence, including "the role of the army" would have meant to unnecessarily increase the number of causal conditions, over-individualize the explanation of each particular case, and counteract the purpose of QCA to reach some degree of parsimony. I therefore opted to exclude the negative case of Gutiérrez from the analysis and preserve the rarer positive case of Fébres.

on which to base a theoretically informed choice of logical remainders, for the purpose of this paper I have opted for the conservative strategy of treating logical remainders as negative configurations. 
The remaining observed combinations are displayed in Table 2 (A complete truth table including unobserved and contradictory configurations is given in Table 4 in the appendix).

Table 2: Truth Table

\begin{tabular}{|c|c|c|c|c|c|c|c|c|}
\hline A & $\mathrm{R}$ & $\mathrm{P}$ & $\mathrm{D}$ & $\mathrm{M}$ & $C$ & $\mathrm{U}$ & Outcome & Case ID \\
\hline 1 & 1 & 1 & 1 & 1 & 0 & 1 & 1 & BOLMes \\
\hline 1 & 0 & 1 & 1 & 0 & 0 & 0 & 1 & BRALul \\
\hline 1 & 0 & 1 & 1 & 0 & 1 & 0 & 1 & COLUri \\
\hline 1 & 1 & 1 & 1 & 0 & 1 & 0 & 1 & ECUFeb \\
\hline 1 & 1 & 1 & 1 & 0 & 0 & 0 & 1 & ECUDur \\
\hline 1 & 1 & 1 & 1 & 1 & 1 & 0 & 1 & ECUAla \\
\hline 0 & 1 & 1 & 0 & 0 & 0 & 0 & 1 & VENCha2 \\
\hline 1 & 1 & 0 & 0 & 0 & 0 & 0 & 0 & $\begin{array}{l}\text { ARGMen1 } \\
\text { ARGMen? }\end{array}$ \\
\hline 1 & 1 & 0 & 1 & 0 & 1 & 1 & 0 & $\begin{array}{l}\text { ARGRua } \\
\text { ARGDuh }\end{array}$ \\
\hline 1 & 1 & 0 & 1 & 1 & 0 & 0 & 0 & $\begin{array}{l}\text { BOLRod } \\
\text { ECUHur }\end{array}$ \\
\hline 1 & 0 & 0 & 0 & 0 & 0 & 0 & 0 & $\begin{array}{l}\text { ARGKir } \\
\text { PERFui2 }\end{array}$ \\
\hline 1 & 0 & 0 & 0 & 1 & 0 & 0 & 0 & BRASar \\
\hline 1 & 0 & 1 & 1 & 0 & 1 & 1 & 0 & BRACol \\
\hline 1 & 0 & 1 & 1 & 1 & 0 & 0 & 0 & BRAFran \\
\hline 1 & 0 & 1 & 1 & 0 & 0 & 1 & 0 & $\begin{array}{l}\text { BRACar1 } \\
\text { BRACar2 } \\
\text { CHIAvl }\end{array}$ \\
\hline 1 & 0 & 1 & 0 & 0 & 0 & 0 & 0 & $\begin{array}{l}\text { CHIFre } \\
\text { CHILag }\end{array}$ \\
\hline 1 & 0 & 0 & 0 & 0 & 1 & 0 & 0 & $\begin{array}{l}\text { COLGav } \\
\text { COLSam }\end{array}$ \\
\hline 1 & 0 & 0 & 1 & 0 & 0 & 0 & 0 & $\begin{array}{l}\text { COLPas } \\
\text { PERTol }\end{array}$ \\
\hline 1 & 1 & 0 & 1 & 0 & 0 & 0 & 0 & $\begin{array}{l}\text { COSPac } \\
\text { ECURol }\end{array}$ \\
\hline 1 & 1 & 0 & 1 & 0 & 1 & 0 & 0 & ECUBor \\
\hline 1 & 1 & 1 & 1 & 0 & 1 & 1 & 0 & $\begin{array}{l}\text { ECUBuc } \\
\text { ECUMah }\end{array}$ \\
\hline 1 & 1 & 1 & 1 & 1 & 0 & 0 & 0 & ECUNob \\
\hline 0 & 1 & 0 & 0 & 0 & 0 & 1 & 0 & $\begin{array}{l}\text { GUACer } \\
\text { GUAPor }\end{array}$ \\
\hline 0 & 1 & 1 & 1 & 0 & 1 & 0 & 0 & GUASer \\
\hline 0 & 1 & 0 & 1 & 1 & 1 & 0 & 0 & GUALeo \\
\hline 0 & 1 & 0 & 0 & 0 & 0 & 0 & 0 & GUAArz \\
\hline 0 & 1 & 1 & 1 & 0 & 0 & 0 & 0 & GUABer \\
\hline 1 & 0 & 0 & 0 & 0 & 1 & 1 & 0 & $\begin{array}{l}\text { NICBar } \\
\text { NICBol }\end{array}$ \\
\hline 1 & 0 & 0 & 1 & 0 & 0 & 1 & 0 & NICAle \\
\hline 0 & 0 & 0 & 0 & 0 & 0 & 0 & 0 & PARRod \\
\hline 0 & 0 & 0 & 1 & 0 & 0 & 1 & 0 & PARWas \\
\hline 0 & 0 & 0 & 0 & 0 & 1 & 1 & 0 & PARCub \\
\hline 0 & 0 & 0 & 1 & 1 & 1 & 0 & 0 & PARGon \\
\hline 0 & 0 & 0 & 1 & 0 & 0 & 0 & 0 & PARDua \\
\hline 1 & 0 & 0 & 0 & 1 & 1 & 1 & 0 & PERFuj3 \\
\hline
\end{tabular}




\section{Minimizing Positive Outcomes}

As can be seen from the truth table, the set of units bearing value [1] on the outcome suggests that the occurrence of a referendum was caused by seven alternative conjunctures of conditions covering seven empirical cases, which highlights that cases are highly individualized. We can now proceed to perform the Boolean minimization. At the root of this process lies the assumption that 'if two Boolean expressions differ in only one causal condition yet produce the same outcome then the causal condition that distinguishes the two expressions can be considered irrelevant and can be removed to obtain a simpler, combined expression' (Ragin, 1987, 93). QCA's minimization procedure reduces the seven causal configurations to a minimal formula consisting of four Boolean terms suggesting that FGIR were produced by four alternative conjunctures of factors.

Equation 1a: Minimal formula for positive outcomes ${ }^{15}$

REFERENDUM = P.D.A.R.M.c.U + P.D.A.R.C.u + P.D.A.m.u + P.d.a.R.m.c.u

Equation 1a can be factored to Equation $1 \mathrm{~b}$ with the administrations explained by each term listed in parentheses (italics indicate cases that are covered by more than one set of conditions).

Equation $1 b$

\begin{tabular}{ccccc}
\hline Referendum = P.D. & (A.R.M.c.U & + A.R.C.u & + A.m.u) & + P.d.a.R.m.c.u \\
\hline & [BOLMes] & [ECUFeb & [BRALul & [VENCha2] \\
& ECUAla] & COLUri & \\
& & ECUFeb & \\
& & ECUDur] & \\
& & & $(3)$ & $(4)$ \\
\hline
\end{tabular}

Equation $1 \mathrm{~b}$ brings $P$ to the fore. That is, a high level of party system fragmentation emerges as the necessary but insufficient condition, which needs to be accompanied by alternative conjunctures of insufficient but non-redundant conditions in order to produce a positive outcome.

\section{Investigation of Positive Cases}

The prominence of $P$ confirms $\mathrm{H} 1$ and indicates that the phenomenon of FGIR in Latin America has been closely related to the difficult combination of presidentialism and multipartism (Mainwaring, 1993). However, $P$ is not the only circumstance that has

15 In the notation for Boolean algebra the logical connectors AND and OR are written "." and "+" respectively. Upper case letters indicate presence of a condition, lower case letters absence. 
brought about the outcome. FGIR are instead due to different interactions of party system fragmentation with several other factors. In six of our empirical cases, this condition was accompanied by a situation of divided government. While in one case (the administration of Mesa in Bolivia) the president was a newcomer to the political scene and thus completely lacked a partisan base of power in the legislature, in two other cases (Uribe in Colombia and Durán in Ecuador) the presidents had longstanding careers in traditional parties but had decided to split from their parties and create new platforms for the upcoming presidential elections. The presidents of the three remaining cases belonged to established parties, which, however, controlled only a small minority of seats in the legislature (Lula's PT in Brazil-17.7 percent, Febrés Cordero's PSC in Ecuador-13.0 percent, and Alarcón's FRA in Ecuador-2.4 percent).

Term (1) covers the administration of President Mesa in Bolivia and combines, $P$ and $D$ with $A, R, M$ and $U$. While the first two conditions do not contribute to an explanation of the outcome given that the respective referendum did not concern constitutional law, the investigation of this case clearly confirms the causal relevance of the latter two conditions, thus confirming $\mathrm{H} 2$ and $\mathrm{H} 5$.

In 2002, presidential candidate Sánchez de Lozada picked Mesa as his running mate. After Lozada had been elected president in a congressional run-off, Mesa assumed office as vice-president. In September 2003, Lozada's backing for a plan to export natural gas to the US sparked violent anti-government protests, which came to be known as the Bolivian 'gas war'. As pressure from the street mounted, Lozada called the army to quell the riots. The excessive use of force deployed by the military led to the deaths of over 50 protesters (Amnesty International, 2004) and caused Lozada's political support to collapse. In October 2003, the National Congress accepted his resignation and installed Mesa as effective head of the executive. Although his assumption of office complied with the constitutional regulations, Mesa lacked a direct popular mandate and needed to distance himself from his unpopular predecessor (Breuer, 2008a). Moreover, upon Mesa taking office, the peasant leaders Morales and Quispe announced a three-month truce after which protest would be resumed should the president fail to deliver on his promise to respond to the gas issue. Against this background and his lack of congressional support, Mesa opted to develop the image of a caretaker president. In his accession speech, he presented a transition cabinet composed of unaffiliated technocrats whose composition sought to pay tribute to the country's ethnic and regional cleavages and pledged to convoke a referendum on the controversial gas issue.

Term (2) combines $P$ and $D$ with the $A, R$ and $C$. The case of Febres' administration in Ecuador, which is covered by this term, offers a paradigmatic illustration of this configurational path towards referendum occurrence. Ecuador's party system is highly fragmented and divided government has been the norm since the country's democratic transition in 1978. This makes it particularly difficult for presidents to achieve the legislative two-thirds majority required for the realization of constitutional reforms. In 1984, the candidate of the Social Christian Party (PSC), León Febres Cordero, won the presidential elections in a tight runoff with support from a loose party alliance known as the National Reconstruction Front (FRN). The preceding January legislative elections had resulted in a highly fragmented 
congress with an ENP of 5.8, within which the FRN held a minority of seats. After Febres' inauguration, conflicts over patronage quickly eroded the cohesion of the FRN while parties of the centre and left joined to form the oppositional Progressive Block, which controlled a majority of seats. Legislative stalemate was a constant feature from the beginning of Febres' administration. An acute crisis, involving physical fights on the legislative floor, erupted in October 1984 when Febres refused to recognize Congress's election of Supreme Court judges sympathetic to the Progressive Block (LAWR 30 November 1984). In the aftermath of this crisis, Febres' heavy reliance on urgent economic decrees, as well as his efforts to block impeachment resolutions against his ministers, further added to the inter-branch hostility (Barczak, 2001b). As the 1986 mid-term elections approached, Febres attempted to alter the course of his ill-fated administration by making use of the Ecuadorian president's prerogative to convoke referendums on constitutional reforms. His proposal requested independent candidates to be able to run for legislative office. By attaching the referendum to the legislative elections, he followed a two-fold strategy, intending, on the one hand, to side-step the lack of the two-thirds legislative majority required for constitutional changes, and on the other hand, relying on a simultaneous translation of a 'Yes' vote on the referendum into votes for pro-Febres candidates in the mid-term elections (LARR 16 May 1986). However, Febres' strategy failed, the electorate rejected the referendum proposal with a clear margin of 58 percent and leftist opposition parties won a solid 60 percent majority of seats in the mid-term elections.

In the case of Fabian Alarcón's administration, the same conditions combined to produce the outcome - although in a different manner and with different dynamics. In February 1997, the Ecuadorian Congress voted to unseat president Bucarám on the grounds of mental incapacity and appointed its own chairman, Alarcón, as effective head of executive. This entailed an executive-legislative crisis given that the Ecuadorian constitution specifies the vice-president as an automatic successor, and the incumbent vice-president, Arteaga, actually asserted her claim to the president's office. The main official objective of the constitutional referendum convoked in May 1997 was thus to legitimize the fait accompli of Bucarám's ouster and Alarcón's succession in office. However, Alarcón's government successfully used the anti-Bucarám sentiment to slip several highly controversial constitutional reform issues into the referendum whose implementation via ordinary legislative proceedings could have proved cumbersome in view of the constitutional rigidity and the minority status of Alarcón's Radical Alfarista Front party, which held only two seats in the legislature.

Term 3_combines $P$ and $D$ with $A$. A revision of the administrations of Durán in Ecuador and Uribe in Colombia, which are covered by this term, confirms that the referendum was caused by the combination of these three factors, since in both cases minority presidents attempted to implement wide-ranging constitutional reforms in the face of intense opposition by highly fragmented congresses.

In May 2002, Alvaro Uribe, a former member of Colombia's Liberal Party who had run as an independent candidate, won the presidential elections in a landslide election. Much of Uribe's electoral success was based on his campaign promise to undertake constitutional reforms in order to tackle Colombia's rampant state corruption. The proposed measures targeted the abolition of long-established privileges of Colombian legislators and the 
suppression of traditional pork barreling practices. The most contentious proposal, however, was to reduce the number of legislators by 43 percent, merge the two chambers of Congress into one, and call for early elections (La Semana 5 August 2002a). While constitutional amendments in Colombia require only ordinary legislative majorities, they involve time-consuming proceedings ${ }^{16}$ and the implementation of Uribe's reform project via the ordinary legislative route would have tied Congress up for months. However, the Colombian constitution provides the president with the possibility to shortcut these proceedings by using a referendum; if an executive referendum proposal on constitutional reform obtains majority consent in both chambers it may be directly submitted to popular vote. Shortly after his inauguration, Uribe presented a draft for a referendum 'against corruption and politicking' to Congress. Against the background of Uribe's popularity, especially the convocation of early elections, represented a threatening scenario to legislators unsupportive of Uribe and was met with respective resistance in the legislature. ${ }^{17}$ Initially, the executive adopted an intransigent posture towards Congress, stating that the referendum was non-negotiable. However as time ran short, the executive concluded that it was preferable to shepherd the referendum through congress before the closure of sessions in December 2002 - albeit at the price of making concessions. The first claim to be abandoned was uni-cameralism (La Semana September 2002), followed by an agreement to reduce the number of legislators by 20 percent instead of the originally envisaged 43 percent. Finally, the executive conceded to drop the claim for congressional dissolution and the convocation of early elections. As preparations for the referendum wore on, it became clear that the government's greatest concern was not whether Colombians would agree to the reform but whether the watered-down proposal would mobilize enough of them to make the vote valid. Supported by the country's business elites, the government launched an unprecedented media campaign urging Colombians to vote. Despite considerable financial efforts, the campaign missed its target. In the referendum vote on 25 October 2003, all but one of the 15 proposed measures fell short of the 6.3 million votes required for passage.

Similarly in 1995, the Ecuadorian minority president Durán Ballén, whose neo-liberal restructuring program had been continuously obstructed by the oppositional majority in Congress, launched a referendum on constitutional reform that proposed, amongst other issues, to equip the president with the power to dissolve congress and call for early legislative elections. However, Durán's popularity had been severely affected by his government's involvement in several corruption scandals and so this rather obvious attempt to install a constitutional dictatorship suffered a resounding defeat at the polls.

Although covered by the same Boolean term, the third case of the Brazilian gun-referendum held under the administration of President Lula in 2005 appears to have followed a different pattern from the cases referred to above, which is not explained by the hypothesized factors. Firstly, the absence of mandatory referendums was irrelevant in this context since the referendum issue did not concern constitutional law. Secondly, the referendum was

16 Proposals have to be debated in both chambers of Congress in two consecutive legislative sessions.

17 In a poll realized by Gallup among parliamentarians, 89 percent of respondents rejected the proposal. 
apparently not born out of executive-legislative conflict. Quite the contrary, the referendum project, which had been initiated by a legislative cross-party bloc was strongly backed by the government (LAWR, 25 October 2005).

Term 4 is distinguished from terms 1 - 3 by the fact that it does not combine $P$ with a situation of divided government. The second administration of Hugo Chávez in Venezuela, which is covered by this term, hence constitutes a deviant case that should be investigated more closely in order to detect additional factors which have not been considered so far and could have contributed to produce the outcome.

After his landslide victory in 1998, in 1999 Chávez managed to dislodge the oppositiondominated congress and replace it with a politically compliant constituent body through an ad-hoc referendum. In July 2000, Chávez stood for reelection and won the presidency with 59.8 percent of the national vote. After the concurrently held legislative elections, party system fragmentation in the new unicameral National Assembly (AN) continued at a relatively high level with an ENP of 4.04. However, Chávez' Fifth Republic Movement (MVR) and the allied Movement towards Socialism (MAS) now controlled 60 percent of its seats. Since the beginning of his administration, Chavez had sought to demolish the country's National Trade Union Confederation (CTV) which he regarded as a bastion of resistance to his project of 'Bolivarian Revolution'. In November 2000, the AN passed an enabling law allowing Chávez to enact laws by decree in several policy areas. Remarkably, despite the fact that the reform of the CTV belonged to one of these areas (LAWR 3 October 2000), Chávez made it clear that a congress-endorsed referendum was his preferred option to promote the project. Although the referendum which was held in December 2000 passed with 69.4 percent yes-votes, it did not produce the expected political victory, and the high abstention rate of 76.5 percent was interpreted as a defeat for the government (The Economist 9 December 2000; El Universal 8 December 2000). To understand why Chavez, having the opportunity to impose his reform project via decree, took the risk of failing at the ballot box, one must be aware of the constraints acting on his administration at that time. Chávez's initial domestic support had mainly been based on his challenge to the traditional political elites whose mismanagement and corrupt exploitation of oil revenues had undermined the people's faith in their political leaders. However, the failure of his 'Bolivarian Revolution' to produce sustainable growth had caused a palpable decline in his popularity (Weyland, 2001). Moreover, Chávez' disrespect for the country's democratic institutions and close relations to the military had drawn harsh criticism, and external pressure on his government, especially from the US, was increasing. Venezuela is the fourth largest supplier of petroleum for the US. Given the meager growth rate, Chávez had grown increasingly dependent on revenues from oil exports to finance his spendthrift clientelistic social policy. After two years, during which the Clinton Administration had avoided major confrontations with Chávez, there were signs that the incoming Bush Administration would adopt a tougher stance against him. Bush maintained close relations with Mexico's new conservative president, Vicente Fox, and Republican foreign experts had stated that the U.S. might turn to Mexico as a more reliable supplier in order to reduce their dependence on Venezuelan oil (The New York Times 27 December 2000). Against this background, the 
referendum on union reform became quasi inescapable; externally, Chávez required the democratic fig leaf of a popular vote to cover his undisguised endeavor to further concentrate political power if he wanted to secure revenues from export sales. Internally, he faced the need to compensate for his administration's lack of output-legitimacy-in the form of a palpable improvement of the economic situation - by demonstrating its input-legitimation through reiterated mobilization of the electorate at the ballot box. External legitimation pressure and an internal lack of output-legitimacy are thus factors that should be considered in future studies on referendum causation.

\section{Minimizing Negative Outcomes}

We can now proceed to perform the QCA-Analysis on the negative cases of our population. Since working hypotheses in this study were formulated to explain positive causation, the Boolean minimization of negative outcomes is not expected to deliver insight on causal conditions for the non-occurrence of referendums. Instead, the purpose of this exercise is to present data on negative cases in a structured, synthesized manner (Rihoux, 2003, 372) that allows for a methodologically informed selection of cases for case studies.

Equation 2: Minimal Formula for Negative Outcomes

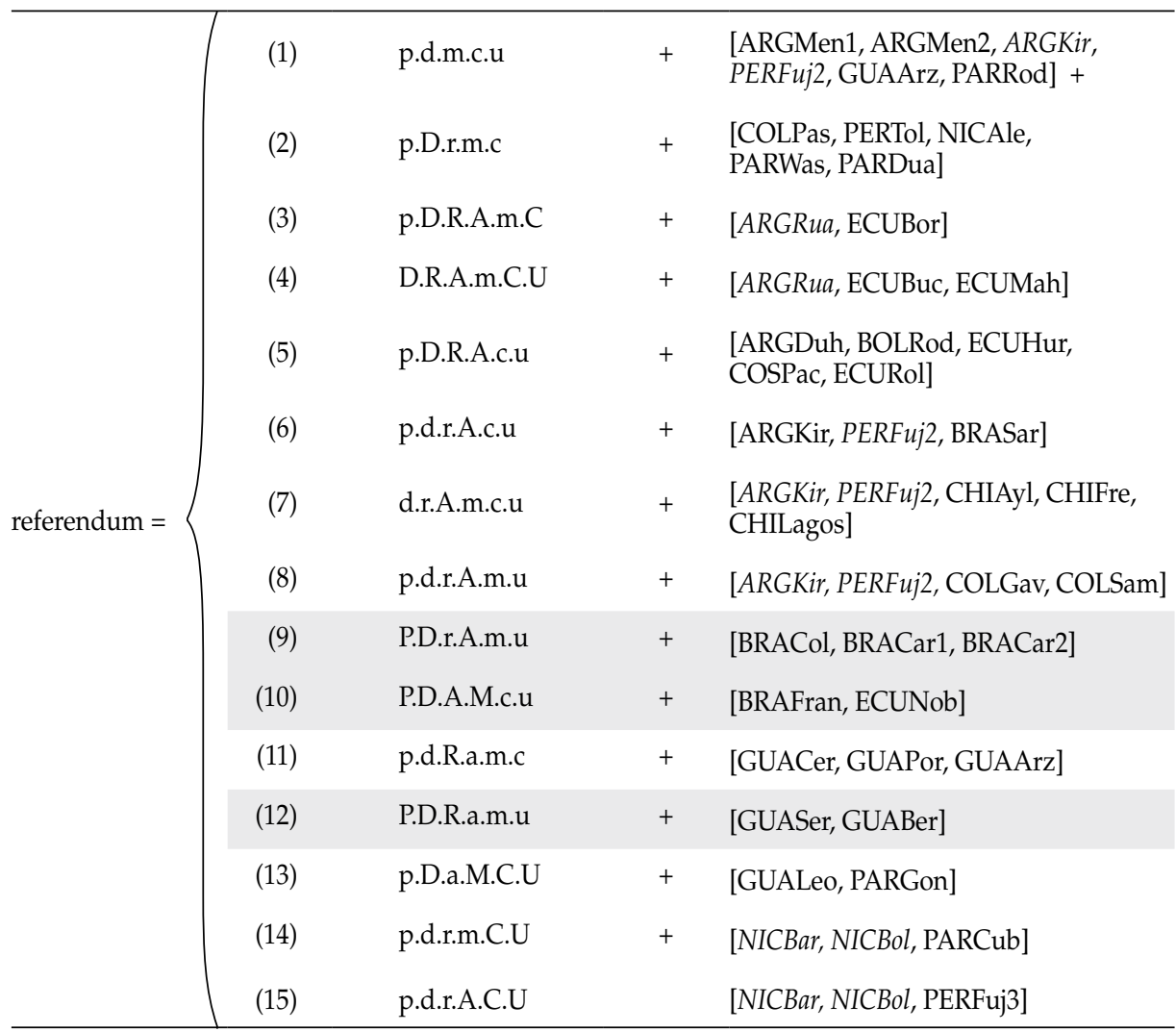


Boolean minimization considerably reduces empirical complexity. In the minimal formula displayed in Equation 2, the 35 empirically observed configurations bearing outcome [0] are reduced to a simpler combined expression consisting of 15 terms. This equation clearly shows that the simple assumption of symmetry of political phenomena is fallacious. In other words, if a specific combination of conditions contributes to the occurrence of a FGIR, we must not automatically deduce that this combination will be absent in cases where a FGIR did not occur. Six negative cases are explained by term (1) in which all of the factors identified as hypothetically relevant for positive causation are absent or were eliminated as redundant, i.e. this term neither runs counter to the formulated working hypotheses and nor to the results obtained from the analysis of positive cases in the preceding section. Terms (9), (10), and (12), by contrast, present an interesting puzzle if compared to the results for Boolean minimization of positive cases, given that the necessary condition $P$ was present and additionally combined with $D$, which was identified as the second most important contributory factor to causation of FGIR. Hence, the administrations covered by these terms presented opportunity structures which should have made the holding of a FGIR an attractive strategy. A closer investigation of these cases is therefore necessary in order to determine whether there were specific conditions, which obstructed an FGIR, or if political actors were able to employ alternative strategies in order to address these critical constellations.

\section{Investigation of Selected Negative Cases}

To shed more light on the specific political opportunity structures obstructive to FGIR, two country administrations were chosen using the MSDO (most similar, different outcome) procedure developed by De Meur and Berg Schlosser (1994) as a technique for case selection. To this purpose, the Boolean distance between positive and negative pairs of administrations - i.e. the number of conditions with different values for the two administrations - were computed and listed in the matrix shown in Table 3.

The level of dissimilarity for the most similar cases with different outcomes (MDSO) in our population is 1 , i.e. these cases differ on only one variable. This applies to 22 case pairs. To further narrow down the selection, I relied on the results of the above QCA analysis. I selected two negative cases which are covered by the critical Boolean terms (11) and (12) of Equation 2 (the administrations of Collor de Mello in Brazil and Serrano in Guatemala) and compared them against their most similar positive pairs (the administrations of Uribe in Colombia and Febres in Ecuador). 
Table 3: Matrix of Boolean Distances

\begin{tabular}{|c|c|c|c|c|c|c|c|}
\hline & BOLMes & BRALul & COLUri & ECUAla & ECUDur & ECUFeb & VENCha2 \\
\hline ARGMen1 & 4 & 3 & 4 & 4 & 2 & 3 & 2 \\
\hline ARGMen2 & 4 & 3 & 4 & 4 & 2 & 3 & 2 \\
\hline ARGRua & 3 & 4 & 3 & 3 & 3 & 2 & 5 \\
\hline ARGDuh & 2 & 3 & 4 & 2 & 2 & 3 & 4 \\
\hline ARGKir & 5 & 2 & 3 & 5 & 3 & 4 & 3 \\
\hline BRASar & 4 & 3 & 4 & 4 & 4 & 5 & 4 \\
\hline BRACol & 3 & 2 & 1 & 3 & 3 & 2 & 5 \\
\hline BRAFran & 2 & 1 & 2 & 2 & 2 & 3 & 4 \\
\hline BRACar1 & 2 & 1 & 2 & 4 & 2 & 3 & 4 \\
\hline BRACar2 & 2 & 1 & 2 & 4 & 2 & 3 & 4 \\
\hline CHIAyl & 4 & 1 & 2 & 4 & 2 & 3 & 2 \\
\hline CHIFre & 4 & 1 & 2 & 4 & 2 & 3 & 2 \\
\hline CHILag & 4 & 1 & 2 & 4 & 2 & 3 & 2 \\
\hline COLGav & 6 & 3 & 2 & 4 & 4 & 3 & 4 \\
\hline COLSam & 6 & 3 & 2 & 4 & 4 & 3 & 4 \\
\hline COLPas & 4 & 1 & 2 & 4 & 2 & 3 & 4 \\
\hline COSPac & 3 & 2 & 3 & 3 & 1 & 2 & 3 \\
\hline ECUHur & 2 & 3 & 4 & 2 & 2 & 3 & 4 \\
\hline ECURol & 3 & 2 & 3 & 3 & 1 & 2 & 3 \\
\hline ECUBuc & 2 & 3 & 2 & 2 & 2 & 1 & 4 \\
\hline ECUMah & 2 & 3 & 2 & 2 & 2 & 1 & 4 \\
\hline ECUNob & 1 & 2 & 3 & 1 & 1 & 2 & 3 \\
\hline ECUBor & 1 & 3 & 2 & 2 & 2 & 1 & 4 \\
\hline GUACer & 4 & 5 & 6 & 6 & 4 & 5 & 2 \\
\hline GUAArz & 5 & 4 & 5 & 5 & 3 & 4 & 1 \\
\hline GUAPor & 4 & 5 & 6 & 6 & 4 & 5 & 2 \\
\hline GUASer & 4 & 3 & 2 & 2 & 2 & 1 & 2 \\
\hline GUALeo & 4 & 5 & 4 & 2 & 4 & 3 & 4 \\
\hline GUABer & 3 & 2 & 3 & 3 & 1 & 2 & 1 \\
\hline NICBar & 5 & 4 & 3 & 5 & 5 & 4 & 5 \\
\hline NICBol & 5 & 4 & 3 & 5 & 5 & 4 & 5 \\
\hline NICALe & 3 & 2 & 3 & 5 & 3 & 4 & 5 \\
\hline PARRod & 6 & 3 & 4 & 6 & 4 & 5 & 2 \\
\hline PARWas & 4 & 3 & 4 & 6 & 4 & 5 & 4 \\
\hline PARCub & 6 & 5 & 4 & 6 & 6 & 5 & 4 \\
\hline PARGon & 5 & 4 & 3 & 3 & 5 & 4 & 5 \\
\hline PARDua & 5 & 2 & 3 & 5 & 3 & 4 & 3 \\
\hline PERFuj2 & 5 & 2 & 3 & 5 & 3 & 4 & 3 \\
\hline PERFuj3 & 4 & 5 & 4 & 4 & 6 & 5 & 6 \\
\hline PERTol & 4 & 1 & 2 & 4 & 2 & 3 & 4 \\
\hline
\end{tabular}


a) Uribe (Colombia, 2002 - 2006) versus Collor de Mello (Brazil, 1990 - 1992)

Similar to his Colombian counterpart Uribe, in 1989 Fernando Collor de Mello split from the Brazilian majority force Democratic Movement Party (PMDB) and founded the Party of National Reconstruction (PRN) for the purpose of the upcoming elections. Backed by wealthy patrons and the media empire $O$ Globo, Collor launched a massive media campaign that put him on top of popularity polls and helped him to defeat his rival Lula da Silva of the Workers Party (PT) with 53 percent in the run-off. Brazilian presidentialism has been traditionally plagued by high party system fragmentation and presidents are usually in a situation of minority government. The same applied for Collor whose PRN controlled only 8.2 percent of seats in the chamber of deputies. In order to secure majority support, he formed a liberal-conservative cabinet including five parties, while the leaders of the PT and PDT immediately forged a leftist opposition bloc (The New York Times 15 March 1990). Brazil's electoral timetable put Collor under considerable time pressure; legislative elections were scheduled for October 1990 and by August 1990, all parties were expected to have joined the opposition and try to attract votes on the strength of his failings (LAWR 1 March 1990). Under these circumstances, Collor resorted to his decree power in order to implement his ambitious neo-liberal reform plan. This tactic won him enemies in congress, with legislators complaining about the president's authoritarian ways of arm-wrestling them into cooperation. In October 1990, the PMDB abandoned the government coalition and joined the opposition (Negretto, 2004). Politically isolated, Collor's government increasingly relied on the distribution of pork in order to secure legislative support (Mainwaring, 1997). During 1991, the opposition continued thwarting most of his proposals and Collor continuously lost the ability to implement policies. In late 1991, he reacted through a television campaign blaming constitutional impediments for the obstruction of his modernization plans and promoted a 44 point constitutional reform -dubbed 'the very big project' or 'emendao'- to restore Brazil's governability (LARR 19 September 1991). Different from the Colombian Constitution, the Brazilian Constitution does not contemplate the possibility of an executive-initiated referendum to short cut constitutional amendment procedures but reserves the right to trigger a referendum and to set its agenda to Congress (Hug and Tsebelis, 2002). Unlike his Colombian counterpart, Collor was thus confined to negotiate every single point of the emendao with the hostile legislature and so it was no surprise that the project soon got stuck in Congress. At the same time, there were signs that a constitutional coup to depose Collor was in the making. According to a temporary provision of the 1988 constitution on 7 September 1993, voters had to decide on the system of government (parliamentary or presidential) to be established in Brazil through a mandatory referendum. In November 1991, 11 parties joined to form a National Parliamentarist Movement (MNP) propagating the parliamentary option and demanding to prepone the referendum to March 1992. Upon the senate's approval of the anticipation proposal in a first reading, Collor reacted by sending his justice minister, Passarinho, to the senate who succeeded in mediating and blocking the final approval which fell three votes short of the three-fifths required for passage. (LAWR 21 November 1991). At the beginning of 1992, Collor tried to stabilize his position by engaging in hectic cabinet-reshuffling. However, he did not manage to broaden his congressional support 
since the PSDB rejected the invitation to join his government, and the rest of his new cabinet members came from parties that already supported him. In May 1992, Collor was accused of leading a nation-wide corruption network and Congress created a joint committee to investigate the case. In a final attempt to avert his overthrow, Collor once again turned to television for his defense, but his telegenic skills had worn out and public indignation led to a civil campaign for his removal. On 29 September 1992, the chamber of deputies approved Collor's impeachment with 441 to 38 votes, while more than 100,000 people demonstrated against the president in front of congress (Perez Liñán).

The comparison between Collor's administration and the positive case of Uribe's administration in Colombia reveals interesting insights with regard to factors that may impede the occurrence of FGIR. In both cases, presidents who had received a sound electoral mandate set out to implement ambitious constitutional reform projects. Once in office, they found themselves in the difficult position of being minority presidents whose reform plans were being obstructed by oppositional majorities in highly fragmented congresses, and in both cases conflict with congress over the implementation of said projects grew into acute crises. However, the two reacted differently to this situation. While Uribe resorted to the referendum, hoping that his popularity and media backing would enable him to realize at least parts of his reform project (Breuer, 2008b), Collor sought to implement his project by engaging in alternative practices such as legislating by decree, patronage, and cabinetreshuffling. Against this background, what factors prevented the Brazilian President from employing the same strategy as his Colombian counterpart? The answer appears to lie in a long-term institutional factor, namely the constitutional provisions regulating the use of referendums in Brazil. While the Columbian Constitution clearly establishes a referendum on the initiative of the executive as an alternative to ordinary constitutional amendment proceedings, this is not the case in Brazil, where the referendum is explicitly defined as a congressional asset by the constitution. Meanwhile, the abortive attempt of Brazilian legislators to oust Collor by means of a referendum indicates that - conversely to the hypothesized effect-high levels of party system fragmentation may be obstructive rather than contributory to the causation of FGIR if the authority to trigger a referendum rests with congress, i.e. a collective actor.

\section{b) Febres (Ecuador, 1984-1988) versus. Serrano (Guatemala, 1991-1993)}

In 1985, Jorge Serrano Elias, a former civil servant and evangelical Christian, founded the Solidarity Action Movement Party (MAS). At that time, Guatemala's fluctuating party system was conformed by a myriad of groups representing the extreme and center-right while still entirely excluding the left from political representation. Thanks to the support of co-religions, Serrano's platform soon found itself a niche in the electoral offer and he won the 1990/91 presidential race in the runoff election. The concurrently held legislative elections had led to a fractionalized Congress with an ENP of 4.6 in which Serrano's MAS only captured 18 of the 116 seats, thus forcing him to form a coalition government with the Christian Democratic Party (DCG) and the neo-conservative Union of the National Center (UCN). During his campaign, Serrano had pledged to implement peace talks with 
the guerrillas and to return law and order to the country after three decades of civil war. In April 1991, his administration took up negotiations with the Guatemalan guerrilla force Revolutionary National Unity (URNG). However after some initial progress, in May 1993, negotiations with the URNG were suspended over controversies regarding how to implement the ceasefire, presenting a blow to Serrano's prestige, in view of the commitment to the peace process declared during his campaign (Perez Liñán). At the same time, Serrano's increasing political isolation induced him to fall back on illegal payoffs to congress members in order to obtain support for his neo-liberal stabilization measures (Perez Liñán). The defection of the DCG from the government coalition further weakened his position. Pre-empting the presentation of a petition for his impeachment on several corruption charges, on 25 May, Serrano staged a self-coup, suspending sections of the constitution, dissolving Congress and the Supreme Court and announcing that elections to a constituent assembly would be held within 60 days. However, the Guatemalan Supreme Electoral Tribunal denied its support and declared his call for elections unconstitutional (LARR 17 June 1993). On 30 May, Serrano reacted to this refusal with a nationally broadcasted address, in which he urged 'political parties and civilian sectors of society' to formulate a consensus proposal for a referendum on constitutional reforms, including guidelines for congressional elections to be held at a later date. However, the opposition rejected this attempt to legitimize his coup, as did the Supreme Electoral Tribunal, which also holds the initiation authority on referendum votes in Guatemala. As international condemnation poured in, the military that had supported the coup wavered, leaving Serrano little choice but to flee to exile.

The comparison between the administrations of Serrano with its most similar positive pair, the administration of Febres in Ecuador, suggests that it was a long-term institutional factor which impeded the occurrence in Serrano's case. Both cases shared the scenario of post-authoritarian states still marked by a near-chronic interference of the military with the recently reestablished civilian governments and in both cases inchoate party systems set the background for a conflictive relation between a highly fragmented congress and a popularly elected minority president. Once conflict had culminated into crisis, both presidents attempted to re-legitimize their shaky administrations through a referendum, however, with differing success. In Ecuador, where the constitution facilitates the president to use FGIR in a virtually unconstrained manner, Febres called a referendum but saw his proposal rejected by the electorate. Meanwhile, Serrano's plans to employ such a strategy were foiled by the fact that the referendum procedure in Guatemala is subject to electoral judicial review, exercised by the Supreme Electoral Tribunal, which denied the necessary authorization.

\section{CONCLUSIONS}

This study set out to fill the gap in our knowledge on the causes of referendums by focusing on the use of FGIR in Latin America's presidential systems. Boolean analysis provided the comparative basis to detect the important factors in referendum causation. Substantively, this analysis showed that referendum occurrence is a complex phenomenon that does 
not lend itself to mono-causal explanations. Contrary to the preponderant view that referendums in presidential systems are a mere byproduct of personalistic, neo-populist leadership, it has been shown that the phenomenon is closely linked to factors which have long been deemed critical for the stability of presidential systems. The working hypotheses on long-and short-term factors drawn from the literature on the 'perils of presidentialism' capture the significant dimensions of opportunity structures conducive to the occurrence of a referendum given that in all positive cases a combination of the hypothesized factors were found. However, two medium-term factors turned out to have a particularly relevant impact: party system fragmentation followed by divided government. This indicates that referendums in presidential systems have to be primarily considered as a strategy to break situations of deadlock, which may typically arise due to the 'difficult combination' of presidentialism and multipartism (Mainwaring, 1993). In such a setting, the decision to hold a referendum can be additionally catalyzed by circumstantial short-term factors like civil unrest, as in the case of Mesa's administration in Bolivia, or acute presidential crises as illustrated by the cases of Febres and Alarcón in Ecuador.

Another interesting result is that, opposite to their hypothesized effect, high levels of party system fragmentation can also obstruct the occurrence of FGIR if the authority to call a referendum is reserved to congress. As shown by the analysis of the Brazilian Collor de Mello administration, in such a situation party system fragmentation can result in failure to achieve the legislative majority which is required for the convocation of a referendum. Future research on referendum causation should thus pay close heed to the different dynamics inherent in legislative and executive initiated referendums.

Meanwhile, conclusions on hypotheses regarding the long-term institutional factors contributive to referendum occurrence are less clear-cut. Although Boolean analysis identified constitutional rigidity and the absence of provisions for mandatory referendums on constitutional reform as non-redundant factors in three configurational paths leading to a referendum, a revision of the empirical cases covered by the respective Boolean terms only partly corroborated this result since in three cases (Mesa in Bolivia, Lula in Brazil, and Chávez in Venezuela) the actual referendum did not concern constitutional law. Instead, long-term institutional factors appear to play a more decisive role in the obstruction of referendums. The comparison of selected negative cases with their most similar positive pairs revealed that in the negative cases, presidents who acted under very similar institutional and situational constraints as their counterparts in the positive cases were effectively hindered from resorting to the referendum tool by the specific constitutional provisions regulating the implementation of this tool. This finding should have important policy implications for those concerned about the potential for manipulative abuse inherent in FGIR since it indicates that this risk can be considerably diminished by appropriate constitutional design.

Since this study looks only at the referendum experience of Latin America's presidential systems, it cannot make conclusions about the worldwide phenomenon. Doubtlessly, the application of the model presented above to parliamentary systems would require substantial modifications that pay heed to the different logics which structure the dynamics of executive legislative interaction in parliamentarism. Notwithstanding, the theoretical 
and methodological approach developed here could provide a fruitful starting point for the study of referendum causation in the semi-presidentialist systems of Central and Eastern Europe, many of which adopted referendum provisions during their transition to democracy.

\section{REFERENCES}

Altman, David. (2000) ,The Politics of Coalition Formation and Survival in Multi-Party Presidential Democracies. The Case of Uruguay, 1989-1999', Party Politics, 6(3), 259-283.

Altman, David. (2005) 'Democracia directa en el continente americano: Autolegitimacion gubernamental o censura ciudadana?', Politica y gobierno 7(2), 203-232.

Altman, David. (2007). 'Myths and Facts about the Use of Direct Democracy Worldwide'. Paper presented at the 2007 ECPR Joint Sessions. Workshop on Referendums and Initiatives, Helsinki, 7-12 May.

Amnesty International (2004) 'Report Bolivia' [online], Available from: http://web.amnesty.org/ report2004/bol-summary-eng

Anckar, Dag, and Karvonen, Lauri. (2002). ,Constitutional Amendment Methods in the Democracies of the World'. Paper presented at XIIIth Nordic Political Science Congress,Aalborg, Denmark, 15-17 August.

Barber, Benjamin. (1984) Strong Democracy: Participatory Politics for a New Age. Berkeley: University of California Press.

Barczak, Monica. (2001a) 'Representation by Consultation? The Rise of Direct Democracy in Latin America', Latin American Politics and Society, 43(3), 37-60.

Barczak, M. (2001b) 'Squaring Off: Executives and Legislatures in Ecuador', in R. Elgie (ed.), Divided Government in Comparative Perspective. Oxford Scholarship Online Monographs, pp. 40-63.

Barr, Robert. (2003) 'The Persistence of Neopopulism in Peru? From Fujimori to Toledo', Third World Quarterly, 24(6), 1161-1178.

BBC 2005. US offers to ease Ecuador crisis. In BBC news, 8 April 2005. Retrieved from http://news.bbc. co.uk/2/hi/americas/4423635.stm, 16 December 2008.

Blondel, Jean. (1968) 'Party Systems and Patterns of Government in Western Democracies', Canadian Journal of Political Science, 1(2), 441-455.

Breuer, Anita. (2008a) 'The Problematic Relation between Direct Democracy and Accountability in Latin America: Evidence from the Bolivian Case', Bulletin of Latin American Research, 27 (1), 1-23.

Breuer, Anita. (2008b) Policymaking by Referendum in Presidential Systems: Evidence from the Bolivian and Colombian Cases', Latin American Politics and Society, 50 (4), 59-89.

Butler, David, and Ranney, Austin. (1994) Referendums around the World. Washington: Macmillan.

Cheibub, José Antonio. (2002a) 'Presidentialism and Democratic Performance', in A. Reynolds (ed.), The Architecture of Democracy. Constitutional Design, Conflict Management, and Democracy. Oxford: Oxford University Press, pp. 105-140.

Cheibub, José Antonio. (2002b) `Minority Governments, Deadlock Situations, and the Survival of Presidential Democracies', Comparative Political Studies, 35(3), 284-312.

Correo del Sur, Sucre, various issues 2004.

Cox, Gary, and Kernell, Samuel. (1991) 'Conclusion', in Gary Cox (ed.), The politics of divided government. Boulder, Colorado: Westview Press, pp. 239-262.

De Meur, Gisèle, and Berg Schlosser, Dirk. (1994) ,Comparing Political Systems: Establishing Similarities and Dissimilarities', European Journal of Political Research, 26(2), 193-219.

El Universal, Caracas, various issues 2000.

El Nacional, Caracas, various issues 2000.

Elgie, Robert. (2001) 'What is Divided Government?', in R. Elgie (ed.), Divided Government in Comparative Perspective. Oxford: Oxford University Press, pp. 2-20.

Ellner, Steve. (2003) 'The contrasting variants of the populism of Hugo Chávez and Alberto Fujimori', Journal of Latin American Studies, 35(1), 139-162. 
Fitch Samuel. 1998. The Armed Forces and Democracy in Latin America. Baltimore: John Hopkins University Press

Franklin, Mark, van der Eijk, Cees., and Marsh, Michael. (1995) ,Referendum Outcomes and Trust in Government', West European Politics. 18, 101-117.

Gerber, Elisabeth R. (1996) 'Legislative Response to the Threat of Popular Initiatives', American Journal of Political Science, 40(1), 99-128.

Go, Julian. 1999. 'Colonial Reception and Cultural Reproduction: Filipino Elites and United States Tutelary Rule'. The Journal of Historical Sociology, 12 (4), 337-368.

Go, Julian. 2008. American Empire and the Politics of Meaning. Elite Political Cultures in the Philippines and Puerto Rico during U.S. Colonialism. Duke University Press.

Hicks, Aexander, Misra, Joya, and Tang, Nah N. (1995) 'The Programmatic. Emergence of the Social Security State', American Sociological Review, 60, 329-349.

Hochstetler, Kathryn. (2006) 'Rethinking Presidentialism: Challenges and Presidential Falls in SouthAmerica', Comparative Politics, 38(4), 401-418.

Hochstetler, Katryn.: Data Set on 'Protest in Presidentialism', Political Science Department, University of New Mexico.

Hug, Simon., and Sciarini, Pascal. (2000) 'Referendums on European Integration', Comparative Political Studies. 33(1): 3-36.

Hug, Simon, and Tsebelis, George. (2002) 'Veto Players and Referendums around the World', Journal of Theoretical Politics, 16(3), 321-356.

Jones, Mark P. (1995), Electoral Laws and the Survival of Presidential Democracies, Notre Dame, IND: University of Notre Dame Press.

Ladner, Andreas., and Brändle, Michael. (1999), 'Does Direct Democracy Matter for Political Parties? An Empirical Test in the Swiss Cantons', Party Politics. 5(3): pp. 283-3.

Lane, Ruth (1992) 'Political Culture. Residual Category or General Theory?' Comparative Political Studies, 25 (3), 362-387

La Razón, La Paz, various issues 2004.

La Semana, Bogotá, various issues 2002-2003.

Latin American Weekly Report (LAWR), various issues.

Latin American Regional Report (LARR), various issues.

Leaman, David. (1995) 'Changing Faces of Populism in Latin America: Masks, Makeovers, and Enduring Features', Latin American Research Review, 39(3), 2004.

LeDuc, Lawrence. (2003) The Politics of Direct Democracy. Toronto: Broadview Press.

Lijphart, Arend. (1984) Democracies. Patterns of Majoritarian and Consensus Government in. Twenty-One Countries, New Haven/London.

Lijphart, Arend. (1999) Patterns of Democracy: Government Forms and Performance in Thirty Six Countries. New Haven, CT: Yale University Press.

Linz, Juan. (1990) ‘The Perils of Presidentialism', Journal of Democracy, 1(1), 51-69.

Linz, Juan, and Stepan, Alfred. (eds.) (1978) The breakdown of democratic regimes. Baltimore London: John Hopkins University Press.

Mackie, John L. (1965). Causes and conditions, American Philosophical Quarterly 2 (4), 245-264.

Mahoney, James, and Goertz, Gary. (2004) 'The Possibility Principle: Choosing Negative Cases in Comparative Research', American Political Science Review, 98(4), 653-669.

Mahoney, James. (2007) 'Qualitative Methodology and Comparative Politics', Comparative Political Studies, $40(2), 122-144$.

Mainwaring, Scott. (1993) 'Presidentialism, Mutipartism, and Democracy. The Difficult Combination', Comparative Political Studies, 26(2), 198-228.

Mainwaring, Scott. (1997) 'Multipartism, Robust Federalism, and Presidentialism in Brazil', in S. Mainwaring and Matthew Sobert Shugart (eds.), Presidentialism and Democracy in Latin America. Cambridge, pp. 55-109.

Mainwaring, Scott, and Shugart, Matthew. (1997) 'Presidentialism and Democracy in Latin America: Rethinking the Terms of the Debate', in Scott Mainwaring and Matthew. Shugart Soberg (eds.), Presidentialism and Democracy in Latin America. Cambridge, pp. 12-53. 
Mayorga, René. (2002) ‘Outsiders and Neopopulism: The Road to Plebiscitarian Authoritarianism' Paper presented at The Crisis of Democratic Representation in the Andes, University of Notre Dame, 13-14 May.

Markoff, John (1990), 'A Comparative Method: Reflections on Charles Ragin's Innovations in Comparative Analysis', Historical Methods, 23, 4, 177-181.

McCoy, Jennifer. (1999) 'Chavez and the End of "Partyarchy" in Venezuela'. Journal of Democracy. 10 (3), 64-77.

Morel, Laurence. (2001) 'The Rise of Government-Initiated Referendums in Consolidated Democracies', in Matthew Mendelsohn, and Andrew Parkin (eds.), Referendum Democracy. Houndmilss: Palgrave, pp. 47-63.

Morgan, Jana. (2007) 'Partisanship during the Collapse of Venezuela's Party'. Latin American Research Review 42 (1), 78-98.

Munck, Gerardo L. (2004) 'Tools for Qualitative Research', in Henry E. Brady and David Collier (eds.), Rethinking Social Inquiry. Diverse Tools, Shared Standards. Oxford: Rowman and Littlefield, pp. 105-121.

Negretto, Gabriel L. (2004) 'Government Capacities and Policy Making by Decree in Latin America', Comparative Political Studies, 37(5), 531-562.

O'Donnell, Guillermo. (1996) 'Delegative Democracy', in Lary Diamond and Marc Plattner (eds.), The Global Resurgence of Democracy. Baltimore: The Johns Hopkins University Press, vol. 5, pp. 55-69.

Papadopulos, Yannis. (2001), 'How Does Direct Democracy Matter? The Impact of Referendum Votes upon Politics and Policy-Making', West European Politics. 24(2), pp. 35-58.

Perez Orlando, Whitney Raymond. 2004. Civil-Military Relations in Latin America: A Case Study of Public Opinion in Ecuador and Paraguay. Paper presented at Annual meeting of The Midwest Political Science Association, Chicago, 15 April 2004.

Pérez-Liñán, Aníbal.: Qualitative Data Set on Presidential Crises in Latin America. Department of Political Science, University of Pittsburgh.

Pérez-Liñán, Aníbal. (2003) 'Pugna de poderes y crisis de gobernabilidad. Hacia un nuevo presidencialismo?', Latin American Research Review, 38(3), 150-164.

Philip, George. (1998) 'The New Populism, Presidentialism and Market-Orientated Reform in Spanish South America', Government and Opposition, 33(1), 81-97.

Pierson, Paul and Skocpol, Theda. (2002) 'Historical Institutionalism in Contemporary Political Science', in Ira Katznelson and Helen. Milner (eds.), Political Science: The State of the Discipline. New York: Norton and Company, pp. 693-721.

Ragin, Charles. (1987) The Comparative Method. Berkeley: University of California Press.

Ragin, Charles. (1992) 'Introduction: Case of "What is a case?"', in Charles Ragin and Howard Becker (eds.), What is a Case? Exploring the Foundations of Social Inquiry. Cambridge: Cambridge University Press, pp. 1-18.

Ragin, Charles., and Rihoux, Benoît . (2004). 'Qualitative Comparative Analysis (QCA): State of the Art and Prospects.' Qualitative Methods: Newsletter of the American Political Science Association Organized Section on Qualitative Methods, 2(2), 3-13.

Ragin Charles., and Sonnett, John. (2004) Between Complexity and Parsimony: Limited Diversity, Counterfactual Cases, and Comparative Analysis. In Sabine Kropp and Michael Minkenberg (Eds) Vergleichen in der Politikwissenschaft. Wiesbaden: VS Verlag für Sozialwissenschaften.

Rahat, Gideon. (2007) ,The Politics of Referendums in Israel. Never Used, Yet a Known and Sometimes Useful Device', Paper presented at the ECPR Joint Sessions of Workshops in Helsinki. 7-12 May.

Redding, Kent, and Viterna, Jocelyn. (1999) ,Political Demands, Political Opportunities: Explaining the Differential Success of Left-Libertarian Parties', Social Forces, 78(2), 491-510.

Rihoux Benoît, Ragin Charles, eds. 2009. Configurational Comparative Methods: Qualitative Comparative Analysis (QCA) and Related Techniques. Thousand Oaks: Sage.

Schmitter, Philippe. (2000) How to Democratize the Euro-Polity and Why Bother. New York: Rowman and Littlefield.

Setälä, Maja. (2006) 'National Referendums in European Democracies. Recent Developments', Direct Democracy and Representation (Special Issue), 42(1), 13-23. 
Setälä, Maja. (2006) 'On the problems of responsibility and accountability', European Journal of Political Research, 45, 699-721.

Suksi, Markku. (1993) Bringing in the People-A Comparison of Constitutional Forms and Practices of the Referendum. Dordrecht: Martinus Nijhof.

The Economist, various issues.

The New York Times, various issues.

Tolbert, Caroline, and Hero, Rodney. (1996), 'Race/Ethnicity and Direct Democracy: An Analysis of California's Illegal Immigration Initiative', The Journal of Politics, 58(3), pp. 806-818.

Van Cott, Donna Lee (2000). The Friendly Liquidation of the Past: The Politics of Diversity in Latin America. Pittsburgh: University of Pittsburgh Press

Vatter, Adrian, and Freitag, Markus. (2006), ,Initiatives, referendums, and the tax state', Journal of European Public Policy, 13(1), pp. 89-112.

Weyland, Kurt. (2001) 'Will Chávez Lose his Luster?', Foreign Affairs (November/December 2001),

Weyland, Kurt. (2003) 'Neopopulism and Neoliberalism in Latin America: How Much Affinity?',Third World Quarterly, 24(6), 1095-1115.

Yamasaki, Sakura. (2003): Testing Hypotheses with QCA: Application to the Nuclear Phase-Out Policy in 9 OECD Countries. Paper presented in the ECPR Conference in Marburg 18. - 21. September 2003.[En línea] ttp://www.essex.ac.uk/ECPR/events/generalconference/marburg/papers/6/5/ Yamasaki.pdf. 
Appendix

Table 4: Truth Table Including Logical Remainders and Contradictory Configurations

\begin{tabular}{|c|c|c|c|c|c|c|c|c|c|}
\hline \multicolumn{8}{|c|}{ Condition } & \multirow{2}{*}{$\frac{\text { Outcome }}{\text { REF }}$} & \multirow{2}{*}{$\mathrm{n}$} \\
\hline row & A & $\mathrm{R}$ & $\mathrm{P}$ & $\mathrm{D}$ & M & C & $\mathrm{U}$ & & \\
\hline 1 & 1 & 1 & 1 & 1 & 1 & 0 & 1 & 1 & 1 \\
\hline 2 & 1 & 0 & 1 & 1 & 0 & 0 & 0 & 1 & 1 \\
\hline 3 & 1 & 0 & 1 & 1 & 0 & 1 & 0 & 1 & 1 \\
\hline 4 & 1 & 1 & 1 & 1 & 0 & 1 & 0 & $\mathrm{C}$ & 2 \\
\hline 5 & 1 & 1 & 1 & 1 & 0 & 0 & 0 & 1 & 1 \\
\hline 6 & 1 & 1 & 1 & 1 & 1 & 1 & 0 & 1 & 1 \\
\hline 7 & 0 & 1 & 1 & 0 & 0 & 0 & 0 & 1 & 1 \\
\hline 8 & 1 & 1 & 0 & 0 & 0 & 0 & 0 & 0 & 2 \\
\hline 9 & 1 & 1 & 0 & 1 & 0 & 1 & 1 & 0 & 1 \\
\hline 10 & 1 & 1 & 0 & 1 & 1 & 0 & 0 & 0 & 3 \\
\hline 11 & 1 & 0 & 0 & 0 & 0 & 0 & 0 & 0 & 2 \\
\hline 12 & 1 & 0 & 0 & 0 & 1 & 0 & 0 & 0 & 1 \\
\hline 13 & 1 & 0 & 1 & 1 & 0 & 1 & 1 & 0 & 1 \\
\hline 14 & 1 & 0 & 1 & 1 & 1 & 0 & 0 & 0 & 1 \\
\hline 15 & 1 & 0 & 1 & 1 & 0 & 0 & 1 & 0 & 2 \\
\hline 16 & 1 & 0 & 1 & 0 & 0 & 0 & 0 & 0 & 3 \\
\hline 17 & 1 & 0 & 0 & 0 & 0 & 1 & 0 & 0 & 2 \\
\hline 18 & 1 & 0 & 0 & 1 & 0 & 0 & 0 & 0 & 2 \\
\hline 19 & 1 & 1 & 0 & 1 & 0 & 0 & 0 & 0 & 2 \\
\hline 20 & 1 & 1 & 0 & 1 & 0 & 1 & 0 & 0 & 1 \\
\hline 21 & 1 & 1 & 1 & 1 & 0 & 1 & 1 & 0 & 2 \\
\hline 22 & 1 & 1 & 1 & 1 & 1 & 0 & 0 & 0 & 1 \\
\hline 23 & 0 & 1 & 0 & 0 & 0 & 0 & 1 & 0 & 2 \\
\hline 24 & 0 & 1 & 1 & 1 & 0 & 1 & 0 & 0 & 1 \\
\hline 25 & 0 & 1 & 0 & 1 & 1 & 1 & 0 & 0 & 1 \\
\hline 26 & 0 & 1 & 0 & 0 & 0 & 0 & 0 & 0 & 1 \\
\hline 27 & 0 & 1 & 1 & 1 & 0 & 0 & 0 & 0 & 1 \\
\hline 28 & 1 & 0 & 0 & 0 & 0 & 1 & 1 & 0 & 2 \\
\hline 29 & 1 & 0 & 0 & 1 & 0 & 0 & 1 & 0 & 1 \\
\hline 30 & 0 & 0 & 0 & 0 & 0 & 0 & 0 & 0 & 1 \\
\hline 31 & 0 & 0 & 0 & 1 & 0 & 0 & 1 & 0 & 1 \\
\hline 32 & 0 & 0 & 0 & 0 & 0 & 1 & 1 & 0 & 1 \\
\hline 33 & 0 & 0 & 0 & 1 & 1 & 1 & 0 & 0 & 1 \\
\hline 34 & 0 & 0 & 0 & 1 & 0 & 0 & 0 & 0 & 1 \\
\hline 35 & 1 & 0 & 0 & 0 & 1 & 1 & 1 & 0 & 1 \\
\hline 36 & 0 & 0 & 0 & 0 & 0 & 0 & 1 & - & 0 \\
\hline
\end{tabular}


Continuación tabla 4

\begin{tabular}{|c|c|c|c|c|c|c|c|c|c|}
\hline \multicolumn{8}{|c|}{ Condition } & \multirow{2}{*}{$\frac{\text { Outcome }}{\text { REF }}$} & \multirow{2}{*}{$\mathrm{n}$} \\
\hline row & $\mathrm{A}$ & $\mathrm{R}$ & $\mathrm{P}$ & $\mathrm{D}$ & $\mathrm{M}$ & $\mathrm{C}$ & $\mathrm{U}$ & & \\
\hline 37 & 0 & 0 & 0 & 0 & 0 & 1 & 0 & - & 0 \\
\hline 38 & 0 & 0 & 0 & 0 & 1 & 0 & 0 & - & 0 \\
\hline 39 & 0 & 0 & 0 & 0 & 1 & 0 & 1 & - & 0 \\
\hline 40 & 0 & 0 & 0 & 0 & 1 & 1 & 0 & - & 0 \\
\hline 41 & 0 & 0 & 0 & 0 & 1 & 1 & 1 & - & 0 \\
\hline 42 & 0 & 0 & 0 & 1 & 0 & 1 & 0 & - & 0 \\
\hline 43 & 0 & 0 & 0 & 1 & 0 & 1 & 1 & - & 0 \\
\hline 44 & 0 & 0 & 0 & 1 & 1 & 0 & 0 & - & 0 \\
\hline 45 & 0 & 0 & 0 & 1 & 1 & 0 & 1 & - & 0 \\
\hline 46 & 0 & 0 & 0 & 1 & 1 & 1 & 1 & - & 0 \\
\hline 47 & 0 & 0 & 1 & 0 & 0 & 0 & 0 & - & 0 \\
\hline 48 & 0 & 0 & 1 & 0 & 0 & 0 & 1 & - & 0 \\
\hline 49 & 0 & 0 & 1 & 0 & 0 & 1 & 0 & - & 0 \\
\hline 50 & 0 & 0 & 1 & 0 & 0 & 1 & 1 & - & 0 \\
\hline 51 & 0 & 0 & 1 & 0 & 1 & 0 & 0 & - & 0 \\
\hline 52 & 0 & 0 & 1 & 0 & 1 & 0 & 1 & - & 0 \\
\hline 53 & 0 & 0 & 1 & 0 & 1 & 1 & 0 & - & 0 \\
\hline 54 & 0 & 0 & 1 & 0 & 1 & 1 & 1 & - & 0 \\
\hline 55 & 0 & 0 & 1 & 1 & 0 & 0 & 0 & - & 0 \\
\hline 56 & 0 & 0 & 1 & 1 & 0 & 0 & 1 & - & 0 \\
\hline 57 & 0 & 0 & 1 & 1 & 0 & 1 & 0 & - & 0 \\
\hline 58 & 0 & 0 & 1 & 1 & 0 & 1 & 1 & - & 0 \\
\hline 59 & 0 & 0 & 1 & 1 & 1 & 0 & 0 & - & 0 \\
\hline 60 & 0 & 0 & 1 & 1 & 1 & 0 & 1 & - & 0 \\
\hline 61 & 0 & 0 & 1 & 1 & 1 & 1 & 0 & - & 0 \\
\hline 62 & 0 & 0 & 1 & 1 & 1 & 1 & 1 & - & 0 \\
\hline 63 & 0 & 1 & 0 & 0 & 0 & 1 & 0 & - & 0 \\
\hline 64 & 0 & 1 & 0 & 0 & 0 & 1 & 1 & - & 0 \\
\hline 65 & 0 & 1 & 0 & 0 & 1 & 0 & 0 & - & 0 \\
\hline 66 & 0 & 1 & 0 & 0 & 1 & 0 & 1 & - & 0 \\
\hline 67 & 0 & 1 & 0 & 0 & 1 & 1 & 0 & - & 0 \\
\hline 68 & 0 & 1 & 0 & 0 & 1 & 1 & 1 & - & 0 \\
\hline 69 & 0 & 1 & 0 & 1 & 0 & 0 & 0 & - & 0 \\
\hline 70 & 0 & 1 & 0 & 1 & 0 & 0 & 1 & - & 0 \\
\hline 71 & 0 & 1 & 0 & 1 & 0 & 1 & 0 & - & 0 \\
\hline 72 & 0 & 1 & 0 & 1 & 0 & 1 & 1 & - & 0 \\
\hline
\end{tabular}


Continuación tabla 4

\begin{tabular}{|c|c|c|c|c|c|c|c|c|c|}
\hline \multicolumn{8}{|c|}{ Condition } & \multirow{2}{*}{$\frac{\text { Outcome }}{\text { REF }}$} & \multirow{2}{*}{$\mathrm{n}$} \\
\hline row & $\mathrm{A}$ & $\mathrm{R}$ & $\mathrm{P}$ & $\mathrm{D}$ & M & C & $\mathrm{U}$ & & \\
\hline 73 & 0 & 1 & 0 & 1 & 1 & 0 & 0 & - & 0 \\
\hline 74 & 0 & 1 & 0 & 1 & 1 & 0 & 1 & - & 0 \\
\hline 75 & 0 & 1 & 0 & 1 & 1 & 1 & 1 & - & 0 \\
\hline 76 & 0 & 1 & 1 & 0 & 0 & 0 & 1 & - & 0 \\
\hline 77 & 0 & 1 & 1 & 0 & 0 & 1 & 0 & - & 0 \\
\hline 78 & 0 & 1 & 1 & 0 & 0 & 1 & 1 & - & 0 \\
\hline 79 & 0 & 1 & 1 & 0 & 1 & 0 & 0 & - & 0 \\
\hline 80 & 0 & 1 & 1 & 0 & 1 & 0 & 1 & - & 0 \\
\hline 81 & 0 & 1 & 1 & 0 & 1 & 1 & 0 & - & 0 \\
\hline 82 & 0 & 1 & 1 & 0 & 1 & 1 & 1 & - & 0 \\
\hline 83 & 0 & 1 & 1 & 1 & 0 & 0 & 1 & - & 0 \\
\hline 84 & 0 & 1 & 1 & 1 & 0 & 1 & 1 & - & 0 \\
\hline 85 & 0 & 1 & 1 & 1 & 1 & 0 & 0 & - & 0 \\
\hline 86 & 0 & 1 & 1 & 1 & 1 & 0 & 1 & - & 0 \\
\hline 87 & 0 & 1 & 1 & 1 & 1 & 1 & 0 & - & 0 \\
\hline 88 & 0 & 1 & 1 & 1 & 1 & 1 & 1 & - & 0 \\
\hline 89 & 1 & 0 & 0 & 0 & 0 & 0 & 1 & - & 0 \\
\hline 90 & 1 & 0 & 0 & 0 & 1 & 0 & 1 & - & 0 \\
\hline 91 & 1 & 0 & 0 & 0 & 1 & 1 & 0 & - & 0 \\
\hline 92 & 1 & 0 & 0 & 1 & 0 & 1 & 0 & - & 0 \\
\hline 93 & 1 & 0 & 0 & 1 & 0 & 1 & 1 & - & 0 \\
\hline 94 & 1 & 0 & 0 & 1 & 1 & 0 & 0 & - & 0 \\
\hline 95 & 1 & 0 & 0 & 1 & 1 & 0 & 1 & - & 0 \\
\hline 96 & 1 & 0 & 0 & 1 & 1 & 1 & 0 & - & 0 \\
\hline 97 & 1 & 0 & 0 & 1 & 1 & 1 & 1 & - & 0 \\
\hline 98 & 1 & 0 & 1 & 0 & 0 & 0 & 1 & - & 0 \\
\hline 99 & 1 & 0 & 1 & 0 & 0 & 1 & 0 & - & 0 \\
\hline 100 & 1 & 0 & 1 & 0 & 0 & 1 & 1 & - & 0 \\
\hline 101 & 1 & 0 & 1 & 0 & 1 & 0 & 0 & - & 0 \\
\hline 102 & 1 & 0 & 1 & 0 & 1 & 0 & 1 & - & 0 \\
\hline 103 & 1 & 0 & 1 & 0 & 1 & 1 & 0 & - & 0 \\
\hline 104 & 1 & 0 & 1 & 0 & 1 & 1 & 1 & - & 0 \\
\hline 105 & 1 & 0 & 1 & 1 & 1 & 0 & 1 & - & 0 \\
\hline 106 & 1 & 0 & 1 & 1 & 1 & 1 & 0 & - & 0 \\
\hline 107 & 1 & 0 & 1 & 1 & 1 & 1 & 1 & - & 0 \\
\hline 108 & 1 & 1 & 0 & 0 & 0 & 0 & 1 & - & 0 \\
\hline
\end{tabular}


Continuación tabla 4

\begin{tabular}{|c|c|c|c|c|c|c|c|c|c|}
\hline \multicolumn{8}{|c|}{ Condition } & \multirow{2}{*}{$\frac{\text { Outcome }}{\text { REF }}$} & \multirow{2}{*}{$\mathrm{n}$} \\
\hline row & A & $\mathrm{R}$ & $\mathrm{P}$ & $\mathrm{D}$ & $\mathrm{M}$ & $\mathrm{C}$ & $\mathrm{U}$ & & \\
\hline 109 & 1 & 1 & 0 & 0 & 0 & 1 & 0 & - & 0 \\
\hline 110 & 1 & 1 & 0 & 0 & 0 & 1 & 1 & - & 0 \\
\hline 111 & 1 & 1 & 0 & 0 & 1 & 0 & 0 & - & 0 \\
\hline 112 & 1 & 1 & 0 & 0 & 1 & 0 & 1 & - & 0 \\
\hline 113 & 1 & 1 & 0 & 0 & 1 & 1 & 0 & - & 0 \\
\hline 114 & 1 & 1 & 0 & 0 & 1 & 1 & 1 & - & 0 \\
\hline 115 & 1 & 1 & 0 & 1 & 0 & 0 & 1 & - & 0 \\
\hline 116 & 1 & 1 & 0 & 1 & 1 & 0 & 1 & - & 0 \\
\hline 117 & 1 & 1 & 0 & 1 & 1 & 1 & 0 & - & 0 \\
\hline 118 & 1 & 1 & 0 & 1 & 1 & 1 & 1 & - & 0 \\
\hline 119 & 1 & 1 & 1 & 0 & 0 & 0 & 0 & - & 0 \\
\hline 120 & 1 & 1 & 1 & 0 & 0 & 0 & 1 & - & 0 \\
\hline 121 & 1 & 1 & 1 & 0 & 0 & 1 & 0 & - & 0 \\
\hline 122 & 1 & 1 & 1 & 0 & 0 & 1 & 1 & - & 0 \\
\hline 123 & 1 & 1 & 1 & 0 & 1 & 0 & 0 & - & 0 \\
\hline 124 & 1 & 1 & 1 & 0 & 1 & 0 & 1 & - & 0 \\
\hline 125 & 1 & 1 & 1 & 0 & 1 & 1 & 0 & - & 0 \\
\hline 126 & 1 & 1 & 1 & 0 & 1 & 1 & 1 & - & 0 \\
\hline 127 & 1 & 1 & 1 & 1 & 0 & 0 & 1 & - & 0 \\
\hline 128 & 1 & 1 & 1 & 1 & 1 & 1 & 1 & - & 0 \\
\hline
\end{tabular}

Dr. Anita Breuer is a Fritz Thyssen scholar at the Department of Comparative Politics, University of Cologne, Germany.

[E-mail: anita.breuer@uni-koeln.de] 
